\title{
Crustal faults in the Chilean Andes: geological constraints and seismic potential
}

\author{
*Isabel Santibáñez ${ }^{1}$, José Cembrano², Tiaren García-Pérez ${ }^{1}$, Carlos Costa ${ }^{3}$, Gonzalo Yáñez², \\ Carlos Marquardt', Gloria Arancibia ${ }^{2}$, Gabriel González ${ }^{5}$
}

\author{
${ }^{I}$ Programa de Doctorado en Ciencias de la Ingeniería, Pontificia Universidad Católica de Chile, Avda. Vicuña Mackenna 4860, \\ Macul, Santiago, Chile. \\ ivsantibanez@uc.cl; trgarcia@uc.cl \\ ${ }^{2}$ Departamento de Ingeniería Estructural y Geotécnica, Pontificia Universidad Católica de Chile, Avda. Vicuña Mackenna 4860, \\ Macul, Santiago, Chile. \\ jcembrano@ing.puc.cl; gyanez@ing.puc.cl; garancibia@ing.puc.cl \\ ${ }_{3}^{3}$ Departamento de Geología, Universidad de San Luis, Ejercito de Los Andes 950, D5700HHW San Luis, Argentina. \\ costa@unsl.edu.ar \\ ${ }^{4}$ Departamento de Ingeniería Estructural y Geotécnica y Departamento de Ingeniería de Minería, Pontificia Universidad Católica \\ de Chile. Avda. Vicuña Mackenna 4860, Macul, Santiago, Chile. \\ cmarquardt@uc.cl \\ ${ }_{5}^{5}$ Departamento de Ciencias Geológicas, Universidad Católica del Norte, Angamos 0610, Antofagasta, Chile. \\ ggonzale@ucn.cl \\ * Corresponding author: ivsantibanez@uc.cl
}

\begin{abstract}
The Chilean Andes, as a characteristic tectonic and geomorphological region, is a perfect location to unravel the geologic nature of seismic hazards. The Chilean segment of the Nazca-South American subduction zone has experienced mega-earthquakes with Moment Magnitudes (Mw) >8.5 (e.g., Mw 9.5 Valdivia, 1960; Mw 8.8 Maule, 2010) and many large earthquakes with $\mathrm{Mw}>7.5$, both with recurrence times of tens to hundreds of years. By contrast, crustal faults within the overriding South American plate commonly have longer recurrence times (thousands of years) and are known to produce earthquakes with maximum $\mathrm{Mw}$ of 7.0 to 7.5. Subduction-type earthquakes are considered the principal seismic hazard in Chile, with the potential to cause significant damage to its population and economy. However crustal (non-subduction) earthquakes can also cause great destruction at a local scale, because of their shallower hypocentral depth. Nevertheless, the nature, timing and slip rates of crustal seismic sources in the Chilean Andes remain poorly constrained. This work aims to address the seismic potential of the crustal faults in Chile, contributing to the estimation of key fault parameters for the seismic hazard assessment. We have examined the main parameters involved in the magnitude of an earthquake, including length, width and mean displacement of some case studies crustal faults and their morphotectonic settings, exposing the parametrical similarities in longitudinal domains (N-S stripes) and disparity from $\mathrm{W}$ to $\mathrm{E}$, across latitudinal domains. The maximum hypocentral depths for crustal earthquakes vary across margin parallel tectonic domains aligned parallel, from $25-30 \mathrm{~km}$ in the outer forearc to $8-12 \mathrm{~km}$ in the volcanic arc, thus allowing for a first-order approach for seismic potential assessment. Current structural, paleoseismological and geodetic data, although sparse and limited, suggest that slip rates of Chilean crustal faults range from $0.2 \mathrm{~mm} / \mathrm{yr}$ (in the forearc region) to up to $7.0 \mathrm{~mm} / \mathrm{yr}$ (in the intra-arc region). The different tectonic modes for crustal fault reactivation and their wide range of slip rates complicates the estimation of seismic hazard. A rigorous seismic hazard assessment must therefore consider the different tectonic settings, timing and slip rates of Andean crustal faults. Understanding the nature of these faults will allow a better evaluation of the associated seismic hazard, and better constraints to be placed on their relationship with the subduction seismic cycle.
\end{abstract}


RESUMEN. Fallas corticales en los Andes chilenos: limitaciones geológicas y potencial sísmico. Los Andes chilenos, entendidos como una región tectónica y geomorfológica característica, son un lugar perfecto para revelar la naturaleza geológica del peligro sísmico. El segmento chileno de la zona de subducción Nazca-Sudamericana ha experimentado mega-terremotos de Magnitud de Momento (Mw) >8,5 (e.g., Mw 9,5 Valdivia, 1960; Mw 8,8 Maule, 2010) y numerosos terremotos de $\mathrm{Mw}>7,5$, ambos tipos con tasas de recurrencia de decenas a cientos de años. En contraste, las fallas corticales en la placa superior sudamericana comúnmente tienen tasas de recurrencia mayores (miles de años) y son conocidas por producir terremotos con magnitud Mw máximas 7,0 a 7,5. Los terremotos del tipo subducción han sido considerados como el principal peligro sísmico en Chile, con el potencial de causar daño importante a la población y economía, pero los terremotos corticales también tienen la capacidad de causar gran destrucción a escala local, debido a la menor profundidad de sus hipocentros. Sin embargo, la naturaleza, las tasas de recurrencia y el deslizamiento de las fallas corticales en Chile están pobremente delimitadas. Este trabajo tiene como objetivo investigar el potencial sismogénico de las fallas corticales en Chile, y contribuir en la estimación de los principales parámetros de las fallas para la evaluación del peligro sísmico. Se examinaron los parámetros principales involucrados en la magnitud de un terremoto, incluyendo largo, ancho y desplazamiento medio de las fallas corticales y su disposición morfotectónica, revelando las similitudes en los parámetros en cada dominio longitudinal (franjas N-S) y una mayor disparidad de W a E (dominios latitudinales). Se muestra que las máximas profundidades de hipocentros corticales cambian en los dominios tectónicos paralelos al margen continental desde 25-30 km en el antearco externo a 8-12 km en el arco volcánico, lo que permite una primera aproximación a la evaluación del potencial sísmico. Aunque dispersos y limitados, los datos estructurales, paleosismológicos y geodésicos actuales sugieren tasas de deslizamiento de las fallas corticales en Chile entre $0,2 \mathrm{~mm} / \mathrm{a}$ (dominio antearco) y 7,0 mm/a (dominio intraarco). Las diferentes condiciones tectónicas de reactivación de las fallas corticales junto al amplio rango de tasas de deslizamiento complican la estimación del peligro sísmico. La investigación rigurosa del peligro sísmico debe considerar los diferentes escenarios tectónicos, las tasas de recurrencia y de deslizamiento de las fallas corticales andinas. Entender la naturaleza de estas fallas nos ayudará no solo a entender mejor el peligro sísmico asociado, sino que también a precisar la conexión con el ciclo sísmico de subducción.

Palabras clave: Fallas corticales, Peligro sísmico, Neotectónica, Terremotos corticales, Paleosismología, Andes chilenos.

\section{Introduction}

Chile is located in an outstanding physical laboratory to investigate the nature of earthquakes and related seismic hazard: The Chilean Andes is a distinctive tectonic and geomorphological orogenic region formed, in the north, by the ocean-continent convergence between the South American and Nazca plates, and in the south by the convergence between the Antarctic and Scotia plates. Its primary features include the Coastal Cordillera, Central Depression and Main and Patagonian Cordillera (e.g., Pankhurst and Hervé, 2007; Ramos, 2009b).

Continental Chile is affected by three main types of earthquakes: subduction, or thrust-type events, due to the Nazca-South America interplate motion, which typically have a hypocentral depth up to 60 km (e.g., Tichelaar and Ruff, 1993; Suárez and Comte, 1993; Allmendinger and González, 2010; Scholz and Campos, 2012); intraplate earthquakes, which occur within the subducting Nazca plate, and typically have hypocentral depths of 60-200 km (e.g., Barrientos, 1980; Campos and Kausel, 1990); and crustal intraplate earthquakes, which occur within the overriding South American plate, and generally have hypocentral depths of less than $30 \mathrm{~km}$ (e.g., Barrientos et al., 2004; Leyton et al., 2010).

The Nazca-South American Chilean subduction zone is capable of producing large magnitude earthquakes with Moment Magnitudes (Mw) greater than 8.5 (e.g., Mw 9.5 Valdivia, 1960; Mw 8.8 Maule, 2010). Earthquake recurrence times in these areas have been estimated at between 80 to 120 years for earthquakes with $\mathrm{Mw}>7.5$, and between 250 to 500 years for earthquakes with $\mathrm{Mw}>8.5$ (Comte et al., 1986; Barrientos and Ward, 1990; Lomnitz, 2004; Cisternas et al., 2005; Barrientos, 2007). Such, "megathrust" subduction type earthquakes are considered the principal seismic hazard in Chile, with the potential to cause significant damage to its population and economy.

Crustal faults within the overriding South American plate (intraplate crustal faults/earthquakes are hereafter named simply "crustal" faults/earthquakes), by contrast, commonly have recurrence times of thousands of years (e.g., Barrientos et al., 2004; Silva, 2008; Leyton et al., 2010) and according to the seismic records are known to produce earthquakes of only moderate magnitudes $\mathrm{Mw}<7.5$, without inducing documented primary surface deformation. However, 
the lack of more detailed seismic and neotectonic studies may have biased our current understanding of crustal faults. Such faults are controlled by contemporary tectonics, or "Neotectonics" (e.g., Mw 6.2, Aysén, 2007, Vargas et al., 2013) or are produced by the reactivation of inherited mechanical anisotropies under a different setting (Paleotectonics) with respect to the present-day stress-field (e.g., Mw 6.9 and Mw 7.0, Pichilemu, 2010, Aron et al., 2013). The term Neotectonics, which has been used variably by previous authors (Mercier, 1976.; Fairbridge, 1981; Hancock and Williams, 1986; Vita-Finzi, 1987; Hancock, 1988; Pavlides, 1989; Mörner, 1994; Costa et al., 2006a), here refers to the study of the processes and structures acting since the contemporary stress field of a given region was established (Stewart y Hancock, 1994). In Chile, this refers to the tectonic system which has been active since at least the start of the Pliocene (González et al., 2003; Cembrano et al., 2007; Ramos 2009a).

The available structural, paleoseismological and geodetic data, though limited, suggest that current slip rates of Chilean crustal faults range from $0.2 \mathrm{~mm} / \mathrm{yr}$ in the fore-arc to up to $6.5 \mathrm{~mm} / \mathrm{yr}$ in the intra-arc (e.g., Wang et al., 2007; Armijo et al., 2010; Cortés et al., 2012; Stanton-Yonge et al., 2016). This implies recurrence times of $\mathrm{Mw}>6$ crustal fault earthquakes in the range of hundreds-to-tens of thousands of years (Sibson, 2002). The various modes of tectonic fault reactivation, and the wide range of slip rates that these faults exhibit, greatly complicate crustal seismic hazard assessment in Chile. Many faults which are considered active under the traditional classification (i.e., over the last 10,000 years, USGS, 2018b) may not be capable of generating significant earthquakes in thousands of years according to their recurrence time (Machette, 2000; Costa, 2004; Costa et al, 2006a), while faults of quaternary age or older, with no instrumentally recorded seismicity, may have the potential to trigger socially consequential earthquakes with $\mathrm{Mw}>7$ (e.g., $2011 \mathrm{Mw} 7.1$ Darfield earthquake, New Zealand; Li et al., 2014).

In this work we attempt to characterize and estimate key crustal fault parameters and general conditions related to their tectonic and geomorphological setting, to introduce a first approximation for the crustal fault seismic hazard assessment (SHA) in Chile. Despite the large epistemic uncertainties involved in most fault data, basic fault conditions parameters were populated in order to better understand the input of geological structures in SHA and also to provide guidance for further investigations in this subject matter.

\section{Geological framework of Chilean Andes crustal faults}

The oceanic Nazca plate subducts beneath the continental South American plate along almost all of the latter's western margin, in a compressional setting defined by Uyeda and Kanamori (1979) as "Chilean type". In Chile, the contact between the two plates runs offshore in a roughly north-south orientation for the majority of the country's length of more than $4,000 \mathrm{~km}$, from the Arica elbow in the north to the Chile ridge subduction site at the NazcaSouth America-Antarctica Triple Junction (latitude $46^{\circ} \mathrm{S}$, Fig. 1). The subducted plate dips $\sim 25-30^{\circ} \mathrm{E}$ beneath South America, except in the central "flat slab" segment, between $28^{\circ}$ and $33^{\circ} \mathrm{S}$, where it dips $\sim 5^{\circ} \mathrm{E}$ with a convergence oblique to the margin $\left(\mathrm{N} 78^{\circ} \mathrm{E}\right.$ ) at a rate of $66-79 \mathrm{~mm} / \mathrm{yr}$ (Cande and Leslie, 1986; DeMets et al., 1994; Angermann et al., 1999) in the strongest compressional-transpressional regime along the Andean margin (Ramos, 2009a).

South of $46^{\circ} \mathrm{S}$ until $\sim 52^{\circ} \mathrm{S}$ the subducting oceanic plate beneath South America is the Antarctic plate, having a convergence rate of $\sim 20 \mathrm{~mm} / \mathrm{yr}$ and a perpendicular to the trench convergence direction from the early Eocene (Cande and Leslie, 1986).

The southernmost tectonic margin of Chile curves to the east and is characterized by a transform boundary between the South American and Scotia plates, whose continental segment is known as the Magallanes-Fagnano fault. This portion of the plate boundary has a left-lateral strike-slip motion estimated between $6.6 \pm 1.3 \mathrm{~mm} / \mathrm{yr}$ to $9.6 \pm 1.4 \mathrm{~mm} /$ yr (Smalley et al., 2003; DeMets et al., 2010). To the west and southwest of this margin, the Antarctic plate subducts beneath the South American plate at a rate of 20-24 mm/yr (Cande and Leslie, 1986; DeMets et al., 1990), and beneath the Scotia plate at a rate of 11-13 mm/yr (Pelayo and Wiens, 1989; Thomas et al., 2003).

The convergence between the Nazca and South American plates has caused crustal shortening and thickening of the overriding (SA) plate, resulting in the formation of the modern Andes mountain range over the past 25 Ma (Mpodozis and Ramos, 1989; Tassara and Yáñez, 1996; Yáñez and Cembrano, 


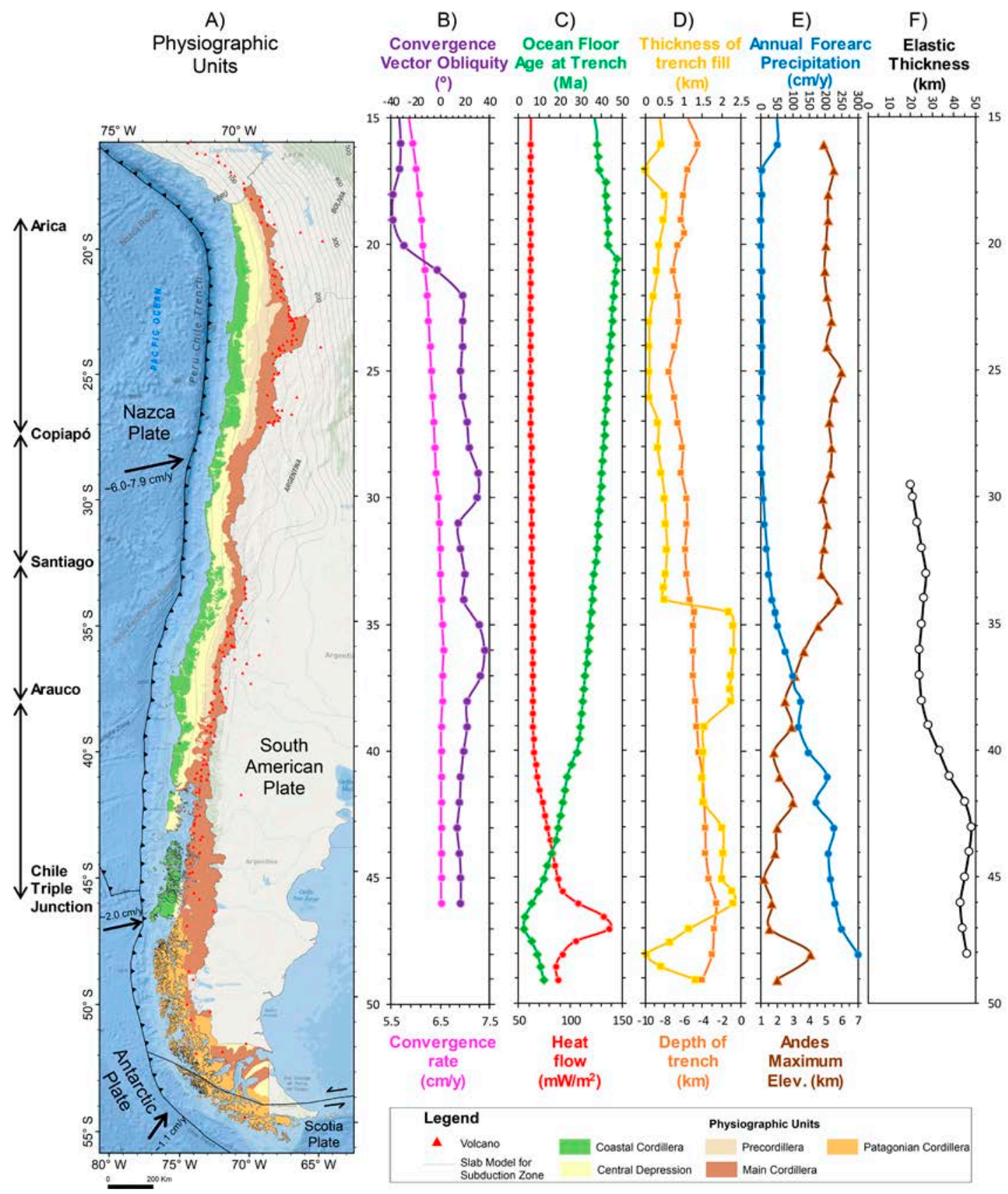

FIG. 1. A. Morphotectonic context and segmentation of the Chilean Andes. Main physiographic units of the Chilean Andes: Coastal Cordillera, Central Depression, Precordillera, Main Cordillera and Patagonian Cordillera (compiled and modified from Mpodozis and Ramos, 1989; Cembrano et al., 2007; Riquelme et al., 2007; Mpodozis and Cornejo, 2012; Armijo et al., 2015). Red triangles symbolize the present-day active volcanoes. Grey lines show depth in km of the SLAB-1 model (Hayes et al., 2012) representing the converging plates interface from the trench (black thick line); The graphs show B. Convergence vector obliquity and convergence rate (Angermann et al., 1999); C. The reducing age of the subducting plate from north to south (Müller et al., 1997) and heat flow from Stein (2003); D. Trench maximum depth in brown diminishing N to S (Lindquist et al., 2004) and its sediment filling depth in yellow (Bangs and Cande, 1997; Hampel et al., 2004) that increases from $33^{\circ} \mathrm{S}$ to south; E. Average annual precipitation along the Chilean fore-arc (New et al., 2002) and topographic elevations of the Andes (Lindquist et al., 2004); and F. The variation of elastic thickness (Tassara and Yáñez, 2003). 
2004; Mpodozis and Ramos, 2008; Ramos, 2009a). The study of the present and past tectonics of the Andes exposes the marked changes that occur along both north-south and east-west transects. First-order tectonic segments have been identified in both the Nazca and the South American plates, ranging from continental scale (e.g., Isacks and Barazangi, 1977; Jordan et al, 1983a; Jordan et al, 1983b; Jarrard, 1986; Yáñez and Cembrano, 2004; Hoffmann-Rothe et al., 2006; Ramos, 2009a) to local scale (e.g., Rosenau, 2004; Rosenau et al., 2006; Rehak et al., 2008), and trending both along- and across-strike. Several factors control this tectonic segmentation, most significantly the absolute motion of the overriding plate and slab retreat, the length of the Benioff zone, the relative plate convergence rate, the direction of mantle flow, climate, the crustal thickness of the South American plate, the age and subduction angle of the Nazca plate, and the subduction of passive and/or active ridges, among others.

The causes of this first-order segmentation are still a subject of debate. Tassara and Yáñez (2003) propose a first-order segmentation caused by a change in the composition of the continental crust from north to south (more felsic in the central Andes $\left(15-33.5^{\circ} \mathrm{S}\right.$ ) against a more mafic crust in the southern Andes (33.5-47 $\mathrm{S}$ ), and a second-order segmentation associated with variations in the thermo-mechanical regime of the plate convergence process. Yáñez and Cembrano (2004) postulate that the arc-foreland deformation is controlled by the absolute velocity of the continental plate and the degree of plate coupling between the oceanic and continental plates, coupling subordinate to the age of the subducting plate and on the convergence rate. Ramos (2009a) indicates that the absolute motion of the upper plate relative to the hotspot frame and the consequent trench rollback velocity are the first order parameters that control the arc-foreland deformation.

Along with fundamental tectonic causes, marked long-term latitudinal climatic variations have been invoked as controlling factors accounting for the geological evolution and segmentation of the continental plate (e.g., Jordan et al., 1983a, b, 2001, 2014; Jarrard, 1986; Mpodozis and Ramos, 1989; Kley et al., 1999; Gutscher et al., 2000; Yáñez et al., 2001; Lamb and Davis, 2003; Tassara and Yáñez, 2003; Yáñez and Cembrano, 2004; Sobolev and Babeyko, 2005; Armijo et al., 2015). Climatic characteristics vary both along and across the Chilean
Andes. Precipitation increases from a hyperarid north to a cold and rainy south, exerting a critical control on the sediment contribution to the trench (Dunai et al., 2005; Hoke, 2006; Kober et al., 2007; Matmon et al., 2009), which is almost empty of sediment fill between $10^{\circ}$ to $33.5^{\circ} \mathrm{S}$. Hyperaridity has likely persisted since at least $c a$. $12 \pm 1 \mathrm{Ma}$ (Jordan et al., 2014) and has been recognized as a key factor on the formation of the Andes (Lamb and Davis, 2003; Jordan et al., 2014). In addition, the Perú-Chile oceanic current and the associated upwelling, induces colder oceanic waters and thus limits precipitation in its vicinity (Lamb and Davis, 2003).

A latitudinal segmentation (across-strike relative to the continental margin/Chilean trench) of the Chilean continental lithosphere into at least five different tectonic domains has been recognized by various authors: Arica-Copiapó, Copiapó-Santiago, Santiago-Arauco, Arauco-Chile Triple Junction, and South of Chile Triple Junction (e.g., Jordan et al., 1983a, b; Tassara and Yáñez, 2003; Yáñez and Cembrano, 2004; Ramos, 2009b; Gerbault et al., 2009). The main tectonic characteristics of these domains are shown in table 1 and figure 1.

There is also a longitudinal segmentation into three main tectonic domains aligned parallel to the Chilean coastal margin: namely, the OuterForearc (OF), Inner-Forearc (IF) and Volcanic Arc (VA). These domains are associated with the main physiographic units of the Chilean Andes: The Coastal Cordillera, Central Depression and Main and Patagonian Cordillera, respectively (Pankhurst and Hervé, 2007). These units correspond broadly to the seismic regionalization proposed by Barrientos (1980) along Chile, which is used by the Chilean Earthquake-resistant design of industrial structures and facilities standard (NCh 433) that only accounts for the subduction earthquake hazard.

The aforementioned tectonic segmentation results in diverse deformation styles and subduction convergence rates along the length of Chile, as exemplified by the different fault systems (compressional, transpressional, normal, strike-slip) and the strain partitioning across the Chilean Andes, which have been active within the same converging regime since the late Cretaceous, and none of which has covered the entire 3,500 km length of the range (Hoffmann-Rothe et al., 2006). Inherited structural anisotropy and current geodynamical conditions further complicate the understanding of the seismogenic 
TABLE 1. LATITUDINAL TECTONIC SEGMENTATION OF CHILEAN ANDES.

\begin{tabular}{|c|c|c|c|c|c|c|c|c|c|}
\hline Segment & $\begin{array}{c}\text { Continental } \\
\text { margin } \\
\text { trend }\end{array}$ & $\begin{array}{c}\text { Subduction } \\
\text { Angle ( }{ }^{\circ} \text { ) }\end{array}$ & $\begin{array}{l}\text { Crustal } \\
\text { Thickness }\end{array}$ & $\begin{array}{c}\text { Elastic } \\
\text { Thickness }\end{array}$ & Coupling & $\begin{array}{l}\text { Volcanic arc } \\
\text { (Actual) }\end{array}$ & $\begin{array}{c}\text { Cenozoic } \\
\text { Andean } \\
\text { shortening }\end{array}$ & $\begin{array}{c}\text { Trench } \\
\text { depth }(\mathbf{k m})\end{array}$ & $\begin{array}{c}\text { Trench } \\
\text { sediment fill } \\
\text { (km) }\end{array}$ \\
\hline $\begin{array}{l}\text { Arica- } \\
\text { Copiapó }\end{array}$ & N-S & $\begin{array}{l}\text { Normal } \\
\sim 25-30^{\circ} \mathrm{E}\end{array}$ & $\begin{array}{l}\text { thick up to } \\
70 \mathrm{~km}\end{array}$ & $\begin{array}{c}\text { low }<10 \mathrm{~km} \\
\text { in } \operatorname{arc}\end{array}$ & high & active & $300-200 \mathrm{~km}$ & $>7.0$ & - \\
\hline $\begin{array}{l}\text { Copiapó- } \\
\text { Santiago }\end{array}$ & $\mathrm{N}-\mathrm{S}$ & $\begin{array}{l}\text { Flat } \\
\sim 5^{\circ} \mathrm{E}\end{array}$ & up to $60 \mathrm{~km}$ & $\begin{array}{c}\text { very low } \\
0-5 \mathrm{~km} \text { in arc }\end{array}$ & - & non active & $200-100 \mathrm{~km}$ & $6.0-6.5$ & $<0.5$ \\
\hline $\begin{array}{l}\text { Santiago- } \\
\text { Arauco }\end{array}$ & NNE & $\begin{array}{l}\text { Normal } \\
\sim 25-30^{\circ} \mathrm{E}\end{array}$ & $\begin{array}{l}\text { high to } \\
\text { normal } \\
<60 \mathrm{~km}\end{array}$ & $\begin{array}{l}\text { medium to } \\
\text { high } \\
<10 \mathrm{~km}\end{array}$ & medium & active & $100-50 \mathrm{~km}$ & $5.0-6.0$ & $0.5-1.0$ \\
\hline $\begin{array}{l}\text { Arauco- } \\
\text { Chile Triple } \\
\text { Junction }\end{array}$ & $\mathrm{N}-\mathrm{S}$ & $\begin{array}{l}\text { Normal } \\
\sim 25-30^{\circ} \mathrm{E}\end{array}$ & $\begin{array}{c}\text { normal to } \\
\text { low } \\
<40 \mathrm{~km}\end{array}$ & $\begin{array}{l}\text { high } \\
>35 \mathrm{~km}\end{array}$ & $\begin{array}{l}\text { medium to } \\
\text { low }\end{array}$ & active & $<50 \mathrm{~km}$ & $<5.0$ & $>1.0$ \\
\hline
\end{tabular}

Data compiled from: Jordan et al., 1983a, b; Tassara and Yáñez, 2003; Yáñez and Cembrano, 2004; Asch et al., 2006; Tassara et al., 2007; Ramos, 2009b; Gerbault et al., 2009.

potential of crustal faults in Chile, considering the subduction as a primal driving source.

The complicated interaction between the Nazca and South American plates has also placed scientific challenges in other Andean countries such as Peru and Ecuador, where the relationship between subduction and crustal seismicity is only just beginning to be understood (e.g., Machare and Ortlieb, 1992; Paris et al., 2000; Machare et al., 2003; Allmendinger and González, 2010; Costa et al., 2010; Alvarado et al., 2014; Yepes et al., 2016; Alvarado et al., 2016).

\section{Use of geological and paleoseismological data in seismic-hazard analysis: issues and challenges}

The amount, repeatability and age of last movement on a fault are often included under the concept of fault "activity" and its related hazard. However, the concept of fault activity has proved to be highly controversial and misleading since it has no agreed definition despite being widely used (Costa et al., 2006a). For example, an "active fault" can refer to one which has undergone slip in either Historic, Holocene or Quaternary times depending on the author (e.g., Wallace, 1986; Yeats et al., 1997; Aki and Lee, 2003; McCalpin, 2009; USGS, 2018b among others). Still other authors define an active fault as one "that may have movement within a future period of concern to humans" (Wallace, 1981), or else fail to define the term at all.

In order to assess the seismic hazard posed by a given fault, it is first necessary to identify whether that fault is capable of generating an earthquake. The seismogenic potential of a fault -that is, the size and recurrence rate of the earthquakes it produces- may be clearer and more tectonically significant when that fault is viewed in the geodynamic context of the subduction earthquake cycle. For example, inactive crustal faults which are optimally oriented with respect to inter- or co-seismic stress fields may be reactivated and produce shallow earthquakes with magnitudes of up to Mw 7 (e.g., Farías et al., 2011; Aron et al., 2013; González et al., 2015). This scenario is particularly relevant for optimally-oriented basement (inherited) crustal faults undergoing sudden high strain rates, a condition which can potentially be achieved co-seismically with large 'megathrust' subduction earthquakes (Mw>8, King et al., 1994; Stein et al., 1994; Stein, 1999; Kilb et al., 2000; Lin and Stein, 2004; Loveless et al., 2010; Seeber and Armbruster, 2000). In contrast, during the inter-seismic period, when the crustal deformation rate is relatively low, the reactivation of optimally-oriented faults may be less likely (e.g., Aron et al., 2014). 
The estimation of earthquake magnitudes from geological data is typically performed using empirical relationships and assumptions of earthquake parameters based on the premise that the rupture parameters of an earthquake are proportional to its magnitude (Slemmons, 1977; Hanks and Kanamori, 1979; Bonilla et al., 1984; Slemmons and de Polo, 1986; Wells and Coppersmith, 1994; Hanks and Bakun, 2008; Wesnousky, 2008; and many others summarized in Stirling et al., 2013). Accordingly, the rupture length and surface displacement which are preserved in the paleoseismological record can be used in empirical regression relationships to estimate earthquake magnitude. The uncertainties of these parameters must be considered, and the assumption that a fault will always rupture with a constant displacement and slip rate thus creating a "characteristic earthquake" must be used with caution (Kagan, 1993; Burbank and Anderson, 2001; McCalpin, 2009). Accordingly, the assessment of the key parameters in the field, and the subsequent estimation of other parameters using empirical relationships, are subject to significant uncertainties (see McCalpin, 2009 for a review).

Models of fault behavior acknowledge that faults may be segmented into discrete sections that act distinctly over their seismic cycle (e.g., Schwartz and Coppersmith, 1986; Slemmons, 1995). Such segmentation can control the onset and termination of fault rupture, and accordingly also the size of the rupture area and earthquake magnitude (Grant, 2002). Commonly, the length of a single fault segment (which may be identified through field observations and/or satellite imagery) indicates the maximum possible surface rupture length during an earthquake, because field features are formed by several ruptures over time. Furthermore, if an inappropriate work scale is chosen, several consecutive segments could be mistaken for a single one. Fault segments which have generated earthquakes independently of each other may additionally be capable of combining into a single segment rupture and thereby generate an earthquake of higher magnitude (e.g., Estay et al., 2016).

Co-seismic displacement of faults is another difficult parameter to assess. Slip from colluvial wedge thickness formed coseismically in dip-slip faults (Nelson, 1992; McCalpin, 2009) assume that the colluvial wedge has not experienced erosion, represents a single event and is representative of the entire rupture zone slip. If all these assumptions are met, the colluvial wedge height is considered to be half of the total slip displacement (McCalpin, 2009). Accordingly, paleoseismological studies should be conducted along the entire length of a fault in order to better represent its behavior. Even when all of this is taken into account, the estimation of earthquake size via paleoseismological or terrain analysis techniques introduces uncertainties which may be difficult to constrain.

\section{Historical and instrumentally recorded crustal earthquakes}

Seismic data is an essential tool with which to constrain and characterize plate tectonics. Major seismic catalogues, such as those maintained by the International Seismological Centre (ISC), National Earthquake Information Centre (NEIC), the ANSS Comprehensive Earthquake Catalog from USGS (2018a), Integrated Plate Boundary Observatory Chie (IPOC) and CMT-Harvard, include data from crustal earthquakes all over the Chilean Andes. Nevertheless, in several cases the hypocentral locations of these events are not sufficiently well constrained to distinguish shallow intra-crustal earthquakes from subduction earthquakes. This is particularly important for events recorded in the forearc, where seismicity in the overriding plate detected from teleseismic observations is often masked by the stronger interplate seismicity. However, catalogue data show a clear concentration of seismicity in the Chilean fore-arc region, in contrast with scarce intraplate crustal seismicity in the Main Cordillera of the Andes (e.g., Pardo et al., 2002; Asch et al., 2006). Along the length of the Central and Southern Andes, intraplate seismicity tends to be localized within the weak lithosphere, where the brittle-ductile transition is located at less than $15 \mathrm{~km}$ depth (Tassara et al., 2007).

There are relatively few published studies documenting crustal earthquakes in Chile (e.g., Pardo et al., 2002; Barrientos et al., 2004). In recent years, the Pichilemu Mw 7.0 earthquake (which struck 12 days after the 2010 Maule interplate mega-earthquake) and the Pisagua Mw 6.7 earthquake (16 days before the 2014 Iquique interplate earthquake) have attracted the attention of geologists and seismologists. These events motivated several studies regarding the nature of these events and their tectonic significance in the subduction cycle, due to their spatial proximity to 
the trench and the fact that they were temporally associated with $\mathrm{Mw} 8.8$ and $\mathrm{Mw} 8.1$ interplate earthquakes (e.g., Farías et al., 2011; Aron et al., 2014; González et al., 2015).

In order to assess the modern crustal seismicity of the Chilean Andes, we used the Harvard CMT catalogue (http://www.globalcmt.org/ (last visit 01/06/2015)), one of the most accurate global seismic event catalogues (Kagan, 2002). When hypocentral depth is undetermined, which is the case on more than $30 \%$ of historical-period earthquakes in the different catalogues, an hypocentral depth based on tectonic setting or nearby seismicity is assigned (Bondar et al., 2015). The CMT catalogue assigns events a "fixed depth solution" with an assumed hypocenter located at 10,15 or $33 \mathrm{~km}$ depth.

A search of the CMT catalogue for earthquakes located in the Chilean Andes, having hypocentral depths shallower than $50 \mathrm{~km}$ and magnitudes above Mw 4.9, and occurring in a 39-year period between January 1976 and April 2015, yielded 6.601 events. Information for each event included date, latitude, longitude, depth, half duration, moment tensor, magnitude metrics ( $\mathrm{Mw}, \mathrm{Ms}, \mathrm{mb}$, etc.) and fault plane solution. From this population we selected 372 earthquakes that were considered to be of crustal origin, by eliminating events that were determined to be subduction-related via analysis of their focal mechanisms, while also eliminating events with poorly determined hypocentral locations. These 372 events are spatially distributed along two bands, one in the coastal outer forearc, and one located inland in the volcanic arc (Fig. 2).

Several earthquakes from this population have been of scientific and/or public interest due to their large magnitude $(\mathrm{Mw}>6.0)$ and shallow hypocentral depth $(<16 \mathrm{~km})$. Epicentral locations of these events are distributed across several different latitudinal and longitudinal domains, and are good models of

FIG 2. Crustal earthquakes recorded in the last 40 years. Location map of 372 crustal earthquakes along the Chilean Andes, with circle sizes corresponding to their magnitude. Focal mechanism of crustal earthquakes with $\mathrm{Mw}>=6$ are displayed. Based on data from Harvard CMT catalogue between January 1976 and April 2015 (The Harvard Centroid Moment Tensor Catalog, http://www.globalcmt. org/ (last visit 01/06/2015)). Also, larger historical crustal events are highlighted: Aroma 2001, Iquique 2015, Las Melosas 1958, Pichilemu 2010, Teno 2004, Aysén 2007 and Magallanes 1949.

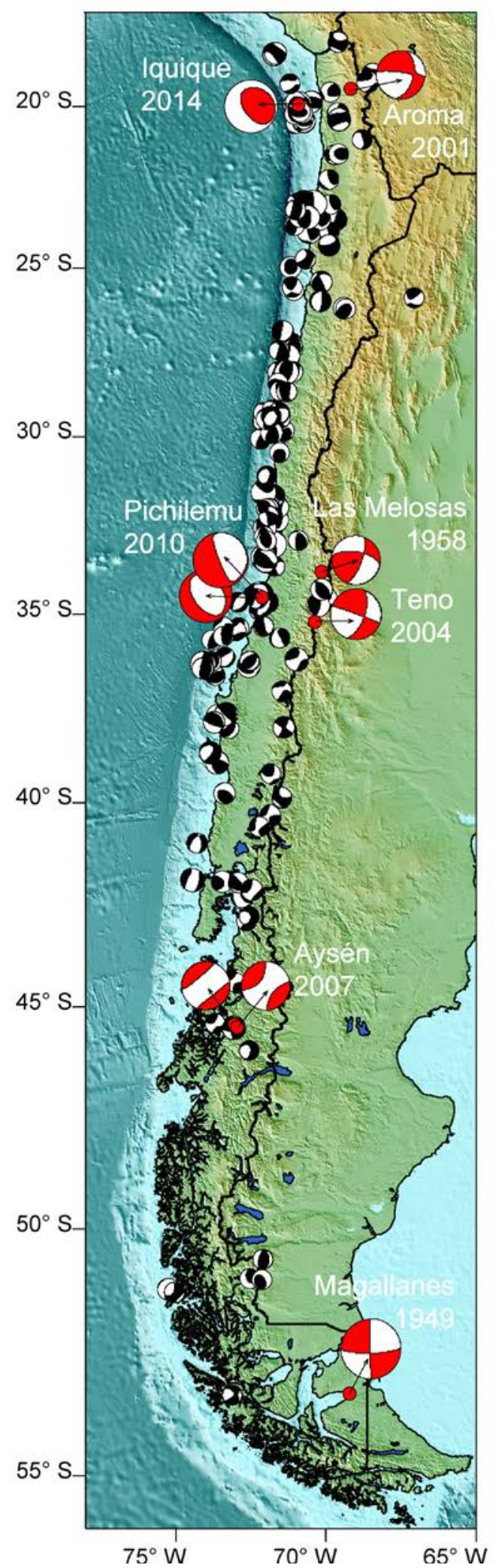


crustal earthquake types as explained in this section (summarized characteristics in table 2). Moreover, the hypocenters and focal mechanisms of some of the earthquakes show strong correspondence with the identified traces and slip characteristics of crustal faults in the region.

In this section, we detail some prominent crustal earthquakes $(\mathrm{Mw}>6.0)$, included in the crustal earthquakes selected from the CMT catalog (Fig. 2).

\subsection{Aroma earthquake (2001), Inner Forearc Domain}

This Mw 6.3 earthquake occurred on July 24, 2001 (Table 2, Fig. 2), and is one of the few shallow earthquakes to have occurred in northern Chile in recent years (Comte et al., 2001). Legrand et al. (2007) used different seismic data to locate the event and its aftershocks. They additionally constrained the focal depth of the event using the SP phase and its focal mechanism. Their analysis produced a fault plane solution of the main event with strike $14^{\circ} \pm 10^{\circ}$, dip $53^{\circ} \pm 15^{\circ}$ and rake $163^{\circ} \pm 15^{\circ}$, indicating dextral movement on an oblique-slip fault. This is consistent with the distribution of aftershocks, which also indicated a fault direction of $\mathrm{N} 14^{\circ} \mathrm{E}$ and dip $50^{\circ}$ E. Additionally, Legrand et al. (2007) determined the earthquake's hypocentral depth to be $5 \pm 1 \mathrm{~km}$, although neither surface deformation nor related morphotectonic features were reported.

\subsection{Las Melosas earthquake (1958), Volcanic Arc Domain}

On September 4, 1958 a seismic event was recorded in the Cordillera Principal of central Chile (Fig. 2), located near the intersection of the Maipo and Volcán rivers (Table 2, Fig. 2), with a hypocentral depth of $15 \mathrm{~km}$. No field evidence of surface rupture associated with this event was observed (Sepúlveda et al., 2008). The

TABLE 2. INSTRUMENTALLY RECORDED CRUSTAL EARTHQUAKES IN CHILE.

\begin{tabular}{|c|c|c|c|c|c|c|c|}
\hline \multirow{2}{*}{ Location } & \multirow{2}{*}{ Year } & \multirow{2}{*}{$\begin{array}{c}\text { Magnitude } \\
\text { Mw }\end{array}$} & \multicolumn{3}{|c|}{ Epicentral Location } & \multirow{2}{*}{ Reference } & \multirow{2}{*}{$\begin{array}{c}\text { Longitudinal } \\
\text { Tectonic } \\
\text { Domain }\end{array}$} \\
\hline & & & Latitude ${ }^{\circ} \mathrm{S}$ & Longitude ${ }^{\circ} \mathrm{W}$ & Depth km & & \\
\hline Aroma & 2001 & 6.3 & 19.5 & 69.2 & $\sim 5.0$ & $\begin{array}{l}\text { Legrand et al., } \\
2007\end{array}$ & Inner Forearc \\
\hline \multirow[t]{2}{*}{ Las Melosas } & 1958 & 6.3 & 33.9 & 70.2 & $5.0-9.0$ & $\begin{array}{l}\text { Alvarado et } \\
\text { al., } 2009\end{array}$ & Arc \\
\hline & & $6.9-6.7-6.8$ & & & & $\begin{array}{c}\text { Sepúlveda et } \\
\text { al., } 2008\end{array}$ & \\
\hline \multirow[t]{2}{*}{ Pichilemu } & 2010 & 6.9 & 34.5 & 72.1 & $\sim 12.9$ & $\begin{array}{c}\text { Farías et al., } \\
2011\end{array}$ & Outer Forearc \\
\hline & & 7.0 & & & 16.3 & $\begin{array}{l}\text { Aron et al. } \\
\quad 2013\end{array}$ & \\
\hline Teno & 2004 & 6.5 & 34.9 & 70.6 & 4.7 & $\begin{array}{l}\text { González, } \\
2008\end{array}$ & Arc \\
\hline \multirow[t]{2}{*}{ Aysén } & $\begin{array}{c}2007 \\
\text { Apr } 21\end{array}$ & 6.2 & 45.4 & 73.0 & $<8.0$ & $\begin{array}{l}\text { Mora et al., } \\
2010\end{array}$ & Arc \\
\hline & & & & & 4.0 & $\begin{array}{l}\text { Legrand et al., } \\
2011\end{array}$ & \\
\hline Aysén & $\begin{array}{l}2007 \\
\text { Apr } 2\end{array}$ & 6.1 & 45.4 & 73.1 & 5.3 & $\begin{array}{c}\text { Legrand et al., } \\
2011\end{array}$ & Arc \\
\hline
\end{tabular}


earthquake involved a sequence of three separate events, with surface wave magnitudes of between Ms 6.7 and 6.9 (Sepúlveda et al., 2008) and momentmagnitudes of Mw 6.3 (Alvarado et al., 2009). For the main event, the focal mechanism determined is consistent either with sinistral slip on a NS-oriented fault plane or dextral slip on a nearly E-W-striking fault plane (Lomnitz, 1960; Sepúlveda et al., 2008; Alvarado et al., 2009; Alfaro, 2011). Sepúlveda et al. (2008) analyzed the hazard associated with the Las Melosas earthquake, estimating intensities and Peak Ground Acceleration (PGA) values from the reinterpretation of historical documents and the study of landslides caused by similar earthquakes. The maximum intensity felt in the epicentral area was 9 (MSK scale), and 6 at a distance of $40 \mathrm{~km}$. Furthermore, according to analysis using the Newmark method of two landslides triggered by this event, the authors estimated a PGA of between 0.58 and $1.30 \mathrm{~g}$. These features highlight the large seismic hazard existing in the vicinity of this blind fault, close to the El Fierro Fault System (Farías et al., 2010).

\subsection{Teno earthquake (2004), Volcanic Arc Domain}

A magnitude Mw 6.7 earthquake occurred on August 28, 2004, in the Cordillera Principal of the Maule region near the headwaters of the Teno river, north of Peteroa volcano (Comte et al., 2008; González, 2008; Alfaro, 2011). According to the National Seismological Service of Chile, the hypocenter was located at $35.2^{\circ} \mathrm{S}, 70.5^{\circ} \mathrm{W}$ and $5 \mathrm{~km}$ depth, with a local magnitude of $M_{L} 6.2$. The Harvard CMT catalog gives a focal mechanism for this event indicating either dextral movement on the fault plane $\mathrm{N} 21^{\circ} \mathrm{E} / 61^{\circ} \mathrm{E}$ and rake $-178^{\circ}$, or sinistral movement on the fault plane $\mathrm{N} 70^{\circ} \mathrm{W} / 88^{\circ} \mathrm{N}$ and rake $-29^{\circ}$. González (2008) relocated the hypocenter at $34.9^{\circ} \mathrm{S}$, $70.5^{\circ} \mathrm{W}$ and $4.7 \mathrm{~km}$ depth. Using aftershock earthquakes placed nearby this structure, she was able to delimit a $\mathrm{N} 20^{\circ} \mathrm{E} / \mathrm{W}$-dipping, $18 \mathrm{~km}$ long and $11 \mathrm{~km}$ deep structure. The same author also suggests a northward spreading of the rupture, from the area of Termas del Flaco to the Maipo river valley, where a Mw 5.6 magnitude earthquake with reverse focal mechanism occurred on September 12, 2004. If we consider the focal mechanism reflecting a NNE-oriented structure and associated dextral fault movement, this earthquake would relate coherently with east-vergent fault systems that reflect the tectonic control proposed by various authors in the southcentral Principal Cordillera area (e.g., El Diablo Fault in Fock, 2005; El Fierro fault in Farías, 2007).

The intensities recorded for the Teno earthquake reveal that only moderate to weak damage was caused in the area: a maximum intensity of VI on the Modified Mercalli scale, while in Talca and Curicó, intensities of V to VI (National Seismological Service) were recorded.

\subsection{Aysén earthquake (2007), Volcanic Arc Domain}

The biggest two earthquakes of a swarm of 7,200 events which occurred within a small area in the Aysen Fjord region in 2007, were the Mw 6.1 and Mw 6.2 earthquakes of April 2007. These events triggered a landslide which induced a tsunami that killed 10 people (Mora et al., 2010; Legrand et al., 2011). The hypocentral depths of the two events have been estimated at less than $12 \mathrm{~km}$ depth, by Legrand et al. (2011), and at $8 \mathrm{~km}$ depth by Mora et al. (2010). Fault plane solutions indicate an almost NS-striking, steeply-dipping nodal plane, consistent with long- and short-term Liquiñe-Ofqui Fault System (LOFS) tectonics, similar to the other events in the swarm. Such earthquakes have also been of interest due to its combined tectonic and volcanic origin (Legrand et al., 2011).

The locations of these earthquakes coincide with the Punta Cola fault (PCF) and with the location of the submarine rupture observed in subsurface profiles. (Vargas et al., 2013; Villalobos-Claramunt et al., 2015). The Punta Cola Fault, a main branch of the LOFS, is a 15-20 km long, N-S-striking, structure that crosses the Aysén Fjord about $5 \mathrm{~km}$ to the east of the main Liquiñe-Ofqui fault (Legrand et al., 2011),

\subsection{Pichilemu earthquakes (2010), Outer Forearc Domain}

A series of crustal earthquakes were felt in the area of Pichilemu for more than a year following the Maule (Mw 8.8) subduction earthquake that affected central Chile on 27 February 2010 (Arriagada et al., 2011; Alfaro, 2011; Farías et al., 2011).

The magnitudes of the main events in this series, which occurred in March 11 2010, were Mw 6.9 and 7.0 (Farías et al., 2011). However, significant 
aftershocks of magnitudes Mw 6.4, 6.1, 6.0 and 5.9 were also recorded. Both the aftershocks and the largest earthquake had normal fault plane solutions (Harvard CMT catalog).

The Mw 6.9 and 7.0 earthquakes were located at $\sim 34.3^{\circ} \mathrm{S}, 71.9^{\circ} \mathrm{W}$, had hypocentral depths of 12 and $20 \mathrm{~km}$ respectively, and had normal type focal mechanism solutions with fault planes $\mathrm{N} 144^{\circ} \mathrm{E} /$ $55^{\circ} \mathrm{SE}$ and $\mathrm{N} 155^{\circ} \mathrm{E} / 74^{\circ} \mathrm{S}$ (Ruiz et al., 2014). The Mercalli intensities of the earthquakes recorded by the ONEMI were VII in Rancagua and VI in Talca while the USGS records intensities of IX near Pichilemu town (Alfaro, 2011).

The earthquake series and its aftershocks correlate spatially with a NW-oriented normal fault, dipping to the SW from the surface to the interplate boundary. Equally oriented extensional fault structures in the region are shown in the 1:1,000,000 scale Chilean geologic map (Sernageomin, 2003).

The 2010-2011 earthquake series has been proposed to have been caused by the large change in Coulomb stress caused by the Maule earthquake (Farías et al., 2011; Aron et al., 2013). These authors link the Pichilemu earthquake with other neotectonic activity, in agreement with the short-term deformation, and suggest that this event might be closely related to the long-term subduction seismic cycle: extensional faulting during coseismic subduction earthquakes and thrusting events in the interseismic period.

\section{Neotectonic crustal faults}

The territory of Chile hosts several prominent crustal faults which have undergone neotectonic activity, and which are predominantly spatially and/or temporally associated with strike-slip fault systems formed by the strain partitioning since at least the middle Jurassic (Hoffmann-Rothe et al., 2006). In this work, we reassess and compile over 1,600 faults from existing publications (Fig. 3). The basis of our work included the compilations of Lavenu et al. (2000), Lavenu (2005), PMA (2009) and SARA (2016).

The main neotectonic crustal faults and fault systems in Chile are spatially distributed across the three main longitudinal tectonic domains that are placed parallel to the Chilean coastline: Outer-forearc (OF), Innerforearc (IF) and Volcanic arc (VA). These domains are additionally crossed by a series of long-lived transverse faults $(\mathrm{T})$. Previous research has primarily focused on geomorphological and tectonic analysis with relatively very few paleoseismological studies. More than 1,000 fault structures regarded as having neotectonic activity but without a rigorous assessment of basic fault parameters are currently under study. This lack of data is largely due to the fact that neotectonic faults are spatially associated with older tectonic structures, making it difficult to separate ancient from recent activity. In the current work we characterize 141 faults using various fundamental parameters for seismic hazard assessment, by compiling information from well-studied faults (Fig. 3).

\subsection{Outer Forearc Domain}

The outer forearc master faults strike predominantly $\mathrm{N}-\mathrm{S}$ and exhibit concave-to-the-west morphologies (e.g., the three segments of the Atacama Fault System, Arabasz, 1971). Regional-scale fault segments are steeply-dipping and have lengths of up to several hundreds of $\mathrm{km}$. These structures commonly display evidence of early strike-slip to late dip-slip displacement. NW-striking subvertical secondary faults splay off the master faults and show similar kinematics. The most relevant faults of the outer forearc domain are the following:

\subsubsection{Atacama Fault System}

The Atacama Fault System (AFS) is a ca. $1,000 \mathrm{~km}$ -long fault zone running along the Coastal Cordillera of northern Chile from Iquique $\left(20^{\circ} \mathrm{S}\right)$ to La Serena $\left(30^{\circ} \mathrm{S}\right)$. The AFS has been the focus of several studies since the late 1960 s due to the prominent geomorphological characteristics that it displays, reflecting a displacement history dating to the Jurassic. Three main segments of the AFS have been identified, all of them curved and concave to the west: Salar del Carmen, Paposo and El Salado (Okada, 1971; Arabasz, 1971; Naranjo, 1987; Hervé, 1987).

The earliest AFS activity is evidenced by mylonitic and cataclastic rocks formed under sinistral displacements in the volcanic arc as result of oblique convergence in the Jurassic-early Cretaceous (Scheuber and Andriessen, 1990; Brown et al., 1993).

Progressive cooling of the magmatic arc in the mid-Cretaceous may have coincided with the AFS deformation changing from ductile to brittle sinistral strike-slip (Brown et al., 1993). The structures generated in this brittle phase of the AFS are duplex-type, limited by NS- and NW-striking 

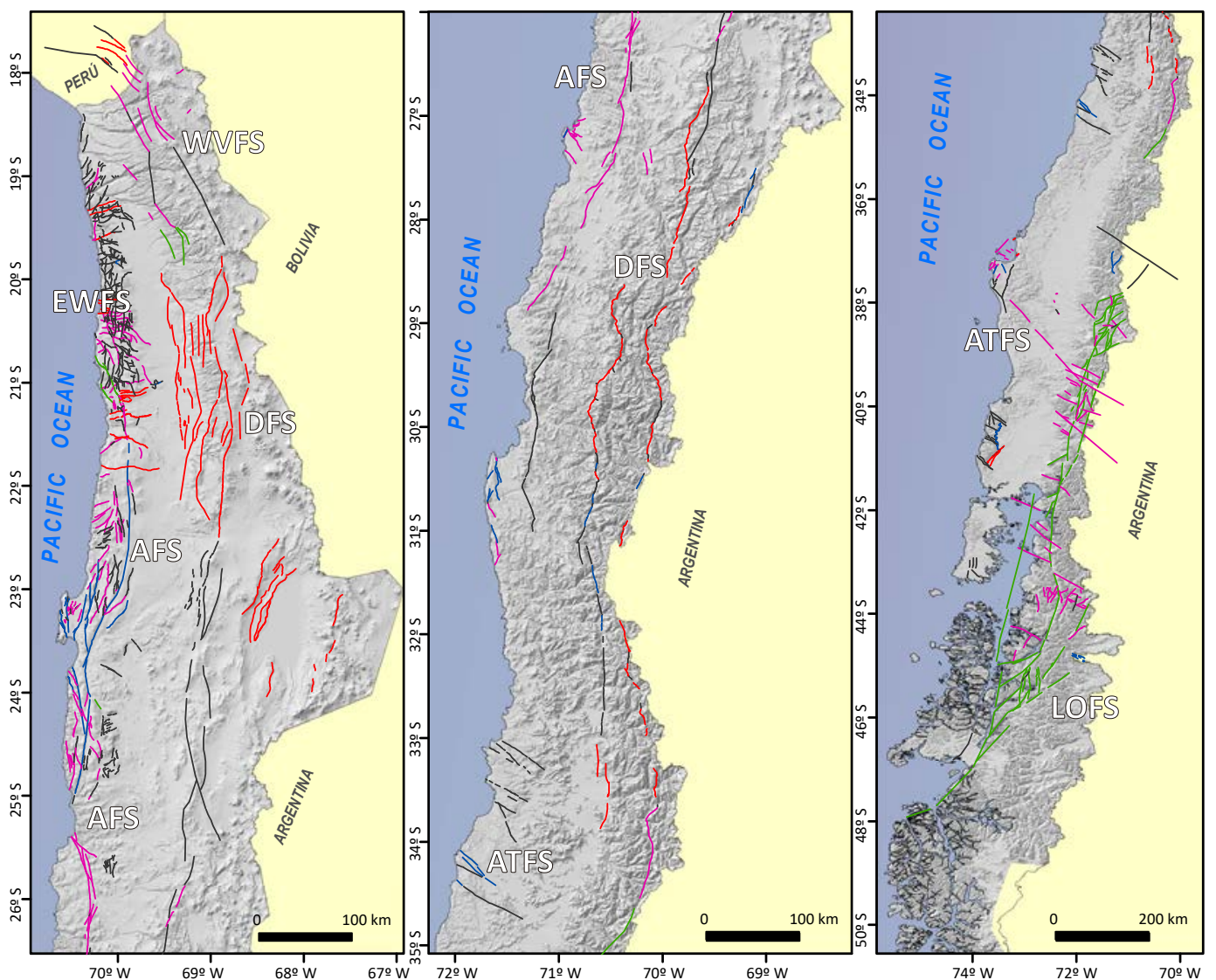

FIG 3. Compilation of Crustal Faults in the Chilean Andes with evidence of neotectonic activity. Normal (blue), Reverse (red), Strike slip dextral (green), Strike-slip Sinistral (magenta) and undetermined (black). Many of them belong to fault systems such as Atacama (AFS), East-West Transversal (EWFS), West Vergent Thrust (WVTS), Domeyko (DFS), Liquiñe-Ofqui (LOFS) faults systems and AndeanTransverse faults (ATF). Only 141 faults have specific studies that allow for a correct categorization as neotectonic faults.

strike-slip faults, segmented into numerous sections each in excess of $60 \mathrm{~km}$ in length (e.g., Cembrano et al., 2005).

Several authors have documented regional-scale sinistral and locally dextral strike-slip displacements along various segments of the AFS. However, the main Neogene-to-recent displacements are normalstyle, consistent with the extensional regime of the present day forearc location (Arabasz, 1971; Okada, 1971; Hervé, 1987; Naranjo, 1987; DeLouis et al., 1998; Scheuber and González, 1999; González et al., 2003; Riquelme et al., 2003; Cembrano et al., 2005; González et al., 2008; Vargas et al., 2011; Allmendinger and González, 2010; Cortés et al., 2012). Quaternary deformation of the AFS is preserved in the horst-and-graben and hemi-graben coastal topography, developing fault scarps from a few meters to over $100 \mathrm{~m}$ in height.

Seismic activity had not been definitively associated with any AFS fault segments until the study of Metcalf and Kapp (2015). These authors compiled crustal seismicity data from existing catalogues, and found extensional focal mechanisms in the forearc region, consistent with the distribution of mapped active fault scarps. This interpretation, however, should be viewed with caution considering that the seismic data used was not obtained from local networks.

One of the best-known AFS fault segments is the Salar del Carmen fault (SCF) that develops near Antofagasta $\left(23^{\circ} \mathrm{S}\right)$ as a $\mathrm{N} 15^{\circ} \mathrm{E}$-striking, $75^{\circ} \mathrm{SE}$ dipping normal fault. Several displaced $\sim 400$ ka old alluvial fan sediments, forming 3 to $5 \mathrm{~m}$-high east 
dipping scarps, reflect the most recent deformation along the AFS (González et al., 2006; Cortés, 2012). These authors constrain the age of the youngest displacement to the late Pleistocene. More recent work, including paleoseismological trenching and Optically Stimulated Luminescence (OSL) dating on colluvial sediments, indicate that SCF has generated at least two earthquakes in the last ca. $5 \mathrm{ka}$, with $\sim 2.2 \mathrm{~m}$ of fault slip for each event. By using Wells and Coppersmith relationships (1994) it has been estimated that each earthquake had a Mw $\sim 7$ (Cortés, 2012).

\subsubsection{Mejillones Fault}

The Mejillones Fault (MF) is a $40 \mathrm{~km}$ long $(30 \mathrm{~km}$ onshore, $10 \mathrm{~km}$ offshore to the north) $\mathrm{N} 10^{\circ}$ E-striking, $75^{\circ} \mathrm{SE}$ - dipping normal fault located in the northern part of the Mejillones Peninsula, $60 \mathrm{~km}$ NW from Antofagasta city. Activity on this fault has been established since at least $3.3 \mathrm{My}$, forming a conspicuous scarp, $\sim 500 \mathrm{~m}$ in height at its northern termination and progressively lowering southward to $\sim 65 \mathrm{~m}$ height (Marquardt, 2005). Its most recent activity is expressed in the deformation of the piedmont area, which formed an escarpment in late Pleistocene alluvial gravels (Marquardt et al., 2004; Cortés et al., 2012). This escarpment has an approximate length of $12 \mathrm{~km}$ and reaches a height of 3 to $10 \mathrm{~m}$.

The MF surface rupture pattern indicates that the fault consists of at least two segments, connected at depth (Cortés et al., 2012). By combining morphological observations, mapping of displaced alluvial surfaces, ${ }^{10} \mathrm{Be}$ dating, OSL dating of colluvial deposits at the foot of the escarpment, and paleoseismological trench mapping, it has been determined that this fault has generated three earthquakes of $\mathrm{Mw} \sim 7$ between $c a .35 \mathrm{ka}$ and $c a .14 \mathrm{ka}$, as well as possibly an earthquake of $\mathrm{Mw} \sim$ 6.6 more recently $(c a .3 \mathrm{ka})$. These results also indicate a slip rate of $0.61 \pm 0.26 \mathrm{~mm} / \mathrm{yr}$, during the first three intervals of the fault evolution, and $0.22 \pm 0.06 \mathrm{~mm} / \mathrm{yr}$ during the fourth interval. The displacement involved in each of these events has been estimated to range from 0.7 to $2.2 \mathrm{~m}$, distributed along rupture surfaces $\sim 40 \mathrm{~km}$ in length and $23 \mathrm{~km}$ in width. Recurrence times for $\mathrm{Mw} \sim 7$ sized earthquakes on the MF have been estimated at $5.0 \pm 3.5 \mathrm{ka}$ (Cortés et al., 2012).

\subsubsection{Caleta Herradura Fault}

The Caleta Herradura fault (CHF) is located in the southwestern half of the Mejillones Peninsula
(Arabasz, 1971; Okada, 1971). Its morphological expression, an escarpment in Quaternary alluvial gravels, suggests that this is a normal fault with conspicuous tectonic activity. The CHF has a length of $\sim 40 \mathrm{~km}$, and five distinct fault sections can be identified. These have accumulated hectometric displacement (Espinoza, 2013; Marquardt, 2005). The state of preservation of the Quaternary scarps is similar to that of the Mejillones Fault, so a late activity of similar age from Pleistocene to Holocene times is inferred (Cortés-Aranda et al., 2015). Ongoing research in neotectonic activity on the fault suggests a transfer of deformation between the Mejillones and Caleta Herradura faults, likely through a connection between the two at around $15 \mathrm{~km}$ depth.

\subsubsection{E-W Fault System}

One of the most distinctive features in the Coastal Cordillera of northern Chile is a series of EW-oriented topographic highs, located between $19^{\circ}$ to $22^{\circ} \mathrm{S}$ latitude, that are spatially associated with eroded fault- and fold-scarps forming the E-W Fault System (EWFS). These scarps are between 20 and $300 \mathrm{~m}$ in height, contain open fractures in 20 to 1600 $\mathrm{m}$-wide zones, and extend from the coastline to the eastern side of the Coastal Cordillera, ending in faultpropagation folds affecting the Central Depression Tertiary infill (Allmendinger et al., 2005; González et al., 2008). The scarps are associated with reverse faults oriented sub-perpendicular to the N-S coastal line, with dip-slip displacement accommodating parallel to the trench shortening (Allmendinger et al., 2005; González et al., 2008; Allmendinger and González, 2010). Some of the scarps are related to emergent reverse faults while others result from surface folding by blind reverse faults.

Morphotectonic and geochronologic studies conducted at a local scale, as well as regional-scale mapping, indicate that the E-W-oriented scarps formed in the late Miocene to early Pliocene, and that activity persisted into the Quaternary (Allmendinger et al., 2005). The scarps blocked the ancient drainage system, leading to the formation of evaporite deposits. The authors suggest that climatic conditions in the Coastal Cordillera were probably wetter during the late Miocene-Pliocene than during the present day. Their results further indicate that the Coastal Cordillera uplifte is younger than mid-Miocene and/or that the Coastal Escarpment has retreated substantively to the east (Allmendinger et al., 2005) and also suggest 
that the origin of the EWFS is linked to the curved continental margin of the Bolivian Orocline, due to its limited latitudinal extent. Concurrently, the EWFS may be associated with north-trending shortening resulting from the oblique convergence between the Nazca and South American plates (e.g., Allmendinger et al., 2005; Carrizo et al., 2008).

The Bajo Molle Fault (BMF), located to the south of Iquique, is one of the nearly EW-striking transversal faults exposed in the coastal active cliff area with a $\mathrm{N} 80^{\circ} \mathrm{E} / 30^{\circ} \mathrm{NW}$ orientation. The most recent activity on this fault is evidenced by a fault propagation fold gentle scarp, placing Jurassic volcanic rocks above late Pleistocene marine deposits (Allmendinger and González, 2010). OSL dating on deformed marine deposits suggests that at least one $\mathrm{Mw} 7.0$ earthquake has occurred in the last $10 \mathrm{ka}$ (González et al., 2015, Supplemental Information). These authors estimated an uplift rate of $0.38 \pm 0.02 \mathrm{~mm} / \mathrm{yr}$, a horizontal shortening rate of $0.135 \pm 0.015 \mathrm{~mm} / \mathrm{yr}$ and a net slip rate of $0.4 \pm$ $0.1 \mathrm{~mm} / \mathrm{yr}$. The rupture displacement calculated for that event is 0.3 to $2.0 \mathrm{~m}$ distributed between the main fault and its branches. Depth of the earthquake source obtained by two methods are $\sim 14 \mathrm{~km}$ (González et al., 2015, Supplemental Information).

\subsubsection{Chomache Fault}

The Chomache Fault $(\mathrm{ChF})$ is a strike-slip fault, aligned $\mathrm{N} 42^{\circ} \mathrm{W} / 78^{\circ} \mathrm{NE}$, and located at $21^{\circ} 10^{\prime} \mathrm{S}$ in the vicinity of Salar Grande. The main evidence of recent activity on this fault is the dextral offset of channels which are developed in Quaternary alluvial surfaces. This deformation pattern occurs along the three main segments of the $\mathrm{ChF}$ with a total length of 20 km (González et al., 2003; Masana et al., 2005; Carrizo et al., 2008; Allmendinger and González, 2010). OSL dating on alluvial/colluvial deposits and paleoseismological trench mapping suggest that at least two seismic events of $\mathrm{Mw} \sim 7$ have occurred along this fault during the last $c a .4 \mathrm{ka}$. The fault displacement for these events has been estimated at between 3 and $6 \mathrm{~m}$, over a rupture area with a length of around $20 \mathrm{~km}$, and a width of no less than $20 \mathrm{~km}$. The time between both events is $\sim 2.1 \mathrm{ka}$, which gives some indication of the recurrence time of $\mathrm{Mw} \sim 7$ earthquakes in $\mathrm{ChF}$.

\subsubsection{Pichilemu Fault}

Two earthquakes, one of Mw 6.9 and one of Mw 7.0, occurred 12 days after the $2010 \mathrm{Mw} 8.8$
Maule megathrust earthquake. These nucleated on the Pichilemu Fault (PF), an upper plate normal fault (Aron et al., 2013). These events showed that the rupture planes have an orientation of $\mathrm{N} 145^{\circ} \mathrm{E} / 55^{\circ} \mathrm{E}$ and $\mathrm{N} 155^{\circ} \mathrm{E} / 74^{\circ} \mathrm{E}$ respectively, and extend down to the plate interface, which lies approximately at 33 $\mathrm{km}$ depth in this region (Farías et al., 2011; Ryder et al., 2012; Aron et al., 2013; Ruiz et al., 2014). Ryder et al. (2012) and Ruiz et al. (2014) suggest that both earthquakes were related to a part of a typical normal fault diverging splay, where the secondary fault connects to the main fault at depth. InSAR and GPS measurements show that $\sim 0.6 \mathrm{~m}$ of vertical offset occurred during the main $\mathrm{Mw} 7.0$ event, and finite slip inversions suggest maximum normal-fault displacements of $\sim 3 \mathrm{~m} \mathrm{(2.4} \mathrm{m}$ along the vertical component) at 10-11 km depth (Ryder et al., 2012).

The main Pichilemu earthquake fault plane has been spatially associated by Aron et al. (2014) with a $141^{\circ}$-striking, SW-dipping normal fault trace mapped in the 1:1.000.000 Chilean geologic map (Sernageomin, 2003). Several studies have concluded that there was no surface rupture associated with the 2010 Pichilemu earthquakes (Arriagada et al., 2011; Farías et al., 2011; Aron et al., 2014). Nevertheless, Aron et al. (2014) state that the geological relations found in the field, such as a record of PleistoceneHolocene (?) uplift of paleo-beach sequences in the footwall, indicate that the Pichilemu fault has repeatedly ruptured the surface in the past and has moved as a normal fault.

\subsection{Inner Forearc Domain}

The inner forearc fault systems exhibit a general NS strike, a sinuous shape and splay faults to both the west and east (e.g., Domeyko fault system, Reutter et al., 1991, 1996). The main fault segments reach tens of kilometers in length, have subvertical dips, and exhibit both dextral and sinistral strike slip movements. There are also reverse faults, such as the West-Vergent Thrust System in northern Chile (Muñoz and Charrier, 1996) and the San Ramón Fault in Central Chile (Vargas et al., 2014).

\subsubsection{Domeyko Fault System}

The Domeyko Fault System (DFS) is an anastomosed system of mostly NS-striking, steeply dipping faults comprising a complex array of strike-slip, normal, and reverse faults, together with 
thin- and thick-skinned folds and thrusts. The DFS is traceable parallel to the Chilean trench for more than $1,000 \mathrm{~km}$ and has a width of between 40 and 60 km (e.g., Reutter et al., 1991, 1996; Cornejo et al., 1997; Lindsay et al., 1995; Mpodozis and Cornejo, 2012). The DFS consists of several regional-scale segments, each of which has undergone distinct deformation events at various times.

The DFS has been active since the upper Eocenelower Oligocene (Reutter et al., 1996), and has contributed to the emplacement and mineralization processes of some of the largest porphyry copper deposits on Earth. Many authors have documented an initial dextral strike-slip movement in the Incaic tectonic phase, followed by sinistral deformation associated with lower convergence rates (e.g., Reutter et al., 1996, Lindsay et al., 1995). The youngest deformation is evidenced by dextral strike-slip fault zones, the same kinematic regime that prevailed during the earliest Eocene-Oligocene phase. Tectonic inversion of this fault system is evidenced by dissimilar displacement amounts: dextral displacement of $0.5-2.0 \mathrm{~km}$, and sinistral displacement of 35-37 km (Reutter et al., 1991; Tomlinson and Blanco, 1997a, b).

Seismic records from the Domeyko Cordillera at $21^{\circ} \mathrm{S}$ show that the present-day activity of the DFS includes, at least in part, both dextral- and reversefaulting kinematics (Salazar, 2011; Bloch et al., 2014). Field observations in the Chuquicamata mine pit document active "en echelon" tension cracks, further supporting ongoing dextral displacement along traces of the DFS (D. Faulkner, T. Mitchell, E. Jensen, personal communication, 2011).

\subsubsection{San Ramón Fault}

Studies carried out along the San Ramón fault (SRF) associate this fault with the structural system that controls the morphotectonic boundary between the Central Depression and the Main Range in central Chile, at a latitude of approximately $33^{\circ} \mathrm{S}$, near the eastern fringe of the Santiago de Chile metropolitan region (Farías, 2007; Armijo et al., 2010; Rauld, 2011). This west-vergent reverse structure is part of the larger West Andean Thrust system, where regional-scale deformation has migrated eastward (Farías, 2007). Surface observations show folded and faulted Eocene-Miocene Abanico Formation volcanoclastic rocks thrusting over Quaternary deposits (Rauld, 2002).
The surface morphology in the region of the SRF is a semi-continuous escarpment that extends northsouth for at least $35 \mathrm{~km}$, from the Mapocho river to the Maipo river (Armijo et al., 2010), decreasing its expression southward. Rauld (2011) applied a kinematic deformation model to the mountain front and piedmont, where a series of west verging kilometric folds affect rocks of the Abanico and Farellones (Miocene) formations. These structures were modeled by the fold-thrust-belt propagation to the west by four reverse faults, with $45-65^{\circ}$ dip, attached to a $4-5^{\circ} \mathrm{E}$ dip detachment plane at 10 $12 \mathrm{~km}$ depth.

Rauld (2011) quantitative study of deformation associated with fault scarps in the Andean piedmont (lower Pleistocene-Holocene deposits) and its morpho-stratigraphic relationship with deformed fluvial terraces of the Maipo and Mapocho rivers, shows fault scarps heights between 3 and $200 \mathrm{~m}$ along 3 segments. The terraces of these rivers, dated using OSL, are deformed by the SRF, suggesting Pleistocene incision rates of 0.5 to $1.0 \mathrm{~mm} / \mathrm{yr}$.

A more recent study using fault trenching and cosmogenic isotope data, documents two large earthquake ruptures (Mw 7.5) on the SRF within the past 8-19 ka; with fault displacements of $\sim 5 \mathrm{~m}$ in each event (Vargas et al., 2014). Other research shows scattered present day seismic activity clustered at around $10 \mathrm{~km}$ depth 20-25 km east of Santiago (Pérez et al., 2014, crustal seismicity recorded between 2000 and 2011). According to Pérez et al. (2014), these data provide the first evidence of seismic activity consistent with the crustal-scale structural model proposed for the SRF system in the area (Armijo et al., 2010). Also, Pérez et al. (2014) model different rupture models for a Mw 6.9 earthquake in the San Ramón Fault, obtaining PGA maximum values in the order of 0.7-0.8 g.

Recently, Estay et al. (2016) defined four segments along the trace of the SRF, with a mean length of $10 \mathrm{~km}$. They used time-integration methodologies to estimate the most likely scenarios of rupture and seismic event distribution along the fault, as well as Transient Electromagnetic (TEM) geophysics to constrain the fault dip angle $\left(65^{\circ}\right)$ and its capacity for surface rupture. By subsequently applying the empirical equation of Chiou and Youngs (2014) for crustal faults and considering the characteristic seismic event (high-angle thrust fault, $10 \mathrm{~km}$ length, Mw 6.2-6.7), the authors also provided estimates 
for the PGA distribution in Santiago that would be caused by such an event, and thereby identified "hazard zones" which are capable of undergoing PGA in excess of $0.5 \mathrm{~g}$.

\subsubsection{West-Vergent Thrust System}

The West-Vergent Thrust System (WVTS) is the largest tectonic feature in the precordillera of northern Chile. The system, of Miocene- Pliocene age, flanks the western reach Altiplano (Muñoz and Charrier, 1996), and has emplaced Precambrian rocks over Neogene rocks. Faults can be observed at the surface at $18^{\circ} \mathrm{S}$, while further south they turn blind, and form surface flexures. The WVTS may be responsible for part of the Altiplano uplift (David, 2007, Farías et al., 2005).

Seismic activity at the WVTS has been documented by David et al. (2002) and Legrand et al. (2007). This activity includes the Mw 6.3 Aroma earthquake of 2001, which had a dextral focal mechanism, similar to WVTS earthquakes reported further south and east by Salazar (2011). Although the Aroma earthquake did not develop a surface rupture, the position of its hypocenter has been correlated with a high angle reverse fault that underlies a regional-scale flexure at the western boundary of the Domeyko Cordillera (Farías et al., 2005).

\subsection{Volcanic Arc Domain}

The volcanic arc faults exhibit roughly north-south strikes with horsetail-type terminations, subvertical dips and strike slip kinematics (e.g., Liquiñe-Ofqui fault system; Cembrano et al., 1996). These develop in the present-day volcanic arc region, where deformation partitioning has taken place from at least the late Miocene.

\subsubsection{Liquiñe-Ofqui Fault System}

The Liquiñe-Ofqui fault system (LOFS) is the most prominent seismogenic crustal fault in the Chilean Andes. It runs for more than $1,200 \mathrm{~km}$ from Copahue Volcano in the north $\left(37^{\circ} \mathrm{S}\right)$ to Golfo de Penas in the south $\left(47^{\circ} \mathrm{S}\right)$, approximately $150 \mathrm{~km}$ SE of the Chile Triple Junction. Early studies by Moreno and Parada (1976), Hervé (1976), and Hervé et al. (1979) recognized the LOFS only along its northern stretch. Later, Forsythe and Nelson (1985) identified and studied the southernmost segments of the LOFS, and postulated a causal link between the
Chile Ridge subduction and Cenozoic activity of the fault system. Field, structural and geochronological studies conducted in the nineties by Pankhurst et al. (1992), Cembrano and Hervé (1993), Cembrano et al. (1996), and Lavenu and Cembrano (1999) provided regional scale constraints on the geometry, nature and timing of ductile to brittle deformation along the fault system. The LOFS is currently regarded as a major dextral strike-slip duplex, associated with both Mio-Pliocene deformation and present day volcanism. In the last decade, more detailed structural and geochronological studies have documented Pliocene ductile-to-brittle transpressional deformation within a regional scale transpressional double-vergent system associated with high exhumation rates during the last $4 \mathrm{Ma}$ (Adriasola et al., 2006; Cembrano et al., 2002, Thomson, 2002; Rosenau et al., 2006).

Brittle fault segments, tens of kilometers in length, commonly overprint pre-existing ductile deformation zones along the LOFS, forming typical strike-slip fault geometries such as duplexes, Riedel-type splay faults, pull apart basins and tension cracks spatially associated with Holocene volcanoes. The master faults have an orientation $\mathrm{N} 10^{\circ} \mathrm{E}$, and subsidiary branches are mainly NE to ENE striking faults.

Teleseismic data and data from local seismic networks show that the LOFS is currently active as a dextral strike-slip fault (e.g., Cifuentes, 1989; Lange et al., 2008; Legrand et al., 2011; Mora et al., 2010; Agurto et al., 2012; Agurto et al., 2014). Recent seismic activity (Aysén Fjord) includes the April 2007 Mw 6.2 dextral strike-slip earthquake, with a hypocentral depth of $4 \mathrm{~km}$, which was the last of a swarm (from January to June 2007) of thousands of lower magnitude quakes, including one normal dip-slip Mw 6.1 earthquake, with a hypocentral depth of $5.3 \mathrm{~km}$, on a NE-striking splay fault (Legrand $e t$ al., 2011). In this paper they re-located 10 events, obtaining hypocentral depths between 1 and $8.5 \mathrm{~km}$. Maximum depths for tectonic seismic activity of $12 \mathrm{~km}$ are reported in Sielfeld et al. (2017).

However, the lack of paleoseismological studies, coupled with the scarcity of exposures of related Quaternary deformation, prevents a more detailed assessment of the Holocene displacement history, and thus the seismogenic potential, of the LOFS. Slip rates can only be roughly estimated from longterm geological data (Adriasola et al., 2006) and short-term, regional-scale, GPS surveys (Wang et al., 2007). Estimates fall in the range of $1-9 \mathrm{~mm} / \mathrm{yr}$, 
decreasing northward (e.g., Rosenau et al., 2006). The boundary element numerical model by StantonYonge et al. (2016) suggests slip rates in the range of 2-7 $\mathrm{mm} / \mathrm{yr}$ for the LOFS master faults. Iturrieta et al. (2017) finite element model results show slip rates of 5 to $10 \mathrm{~mm} / \mathrm{yr}$ for the eastern master fault, whereas the western and subsidiary faults display rates of 1 to $5 \mathrm{~mm} / \mathrm{yr}$.

\subsection{Other crustal faults}

\subsubsection{Andean Transverse Faults}

The Andean Transverse Faults (ATF) are deepseated lithospheric-scale structural elements that cross all margin-parallel tectonic domains. These structures display various alignments; the most conspicuous ones are the arc-oblique WNW-striking fault systems as defined by Pérez-Flores et al. (2016), based on the previous work of several authors (e.g., Cembrano et al., 1996; Yáñez et al., 1998; Rosenau et al., 2006; Cembrano and Lara, 2009; Sánchez et al., 2013). ATF are well developed from the Andes main cordillera to the coastal cordillera between $33^{\circ}$ and $46^{\circ} \mathrm{S}$. The ATF comprises a series of discrete faults, with a predominantly NW strike, that are spatially or genetically related to either of the following features and/or processes: 1) Regional basin boundaries (e.g., Radic, 2010); 2) Location of several ore deposits (e.g., Chernicoff et al., 2002); 3) Subduction earthquakes rupture zones (Melnick et al., 2009); 4) Quaternary volcanism in the Central and Southern Andes (Cembrano and Lara, 2009; Cembrano and Moreno, 1994; Lara et al., 2004, 2006; Sánchez et al., 2013; Tibaldi et al., 2005). The ATF exhibits evidence of long-term fluid flow pathways, volcanic activity and shallow seismic activity (Haberland et al., 2006; Lara et al., 2006, 2004; Sánchez et al., 2013; Tardani et al., 2016). Segments of these faults are included in the longitudinal classification of this paper, as is the Pichilemu fault in the outer arc domain, because fault segments act as independent faults; there is no record of one entire fault within the ATF system with neotectonic displacement. Consequently, although ATF have prominent, long traces in surface by their behavior respond well to the domain characteristics.

Other prominent ATF are the Lanalhue Fault, which interseismic transpressional deformation in the forearc $\left(38^{\circ} \mathrm{S}\right)$ include a $\mathrm{M}_{\mathrm{L}} 5.2$ earthquake at $12 \mathrm{~km}$ depth with a left-lateral focal mechanism
(Haberland et al., 2006) and the Biobío-Alumine Fault System (Melnick et al., 2006; Muñoz and Stern, 1988).

The seismic activity observed with a temporal network in the Haberland et al. (2006) work in the Arauco Peninsula shows seismicity in the continental crust situated between 10 and $30 \mathrm{~km}$ depth. They associated those earthquakes, in most cases, with mapped faults, revealing that these faults are almost all forearc crust deep.

\subsubsection{Magallanes-Fagnano Fault System}

The 600 km-long Magallanes-Fagnano Fault (MFS) is a transform-type margin, and one of the major segments of the continental South Americaoceanic Scotia plate boundary. The MFS runs from the western arm of the Magallanes Strait, where the South American-Scotia-Antarctic plates triple junction is located, to the offshore Atlantic. It transects the Isla Grande of Tierra del Fuego into two continental blocks (Lodolo et al., 2002, 2003; Cisternas and Vera, 2008; Civile et al., 2012).

Lodolo et al. (2003) describe the MFS as consisting of distinct tectonic lineaments that are segments of the transform system and predominantly consists of near-vertical faults. In their study of the asymmetric basin sediments they suggest a close relation between strike-slip motion and transform-normal extensions, a common feature found in other continental transtensional environments.

South of the South American-Nazca-Antarctic plates triple junction, the South American and Antarctic plates converge at a rate of $c a .1 .9 \mathrm{~cm} / \mathrm{y}$, in a margin-perpendicular way in the north varying to strongly oblique in the south. To the south, the convergence rate is reduced to $<1.2 \mathrm{~cm} / \mathrm{y}$ since part of the convergence is accommodated by the MFS at a $<0.5$ to $0.7 \mathrm{~cm} / \mathrm{y}$ rate (Lodolo et al., 2003; Cisternas and Vera, 2008). This convergence is almost perpendicular at $52^{\circ} \mathrm{S}$, but rapidly becomes oblique to the south reaching $60^{\circ}$ at $57^{\circ} \mathrm{S}$.

In Magallanes, two important historical earthquakes of $M_{L}=7.5 ; M_{S}=7.8$ occurred, in 1879 and 1949 respectively (Lomnitz, 1970; Cisternas and Vera, 2008; Costa et al., 2006b). Recent seismicity, recorded in 1997 and 1998, of lower magnitude $\mathrm{M}_{\mathrm{L}}=4.3$, occurred within the continental crust. Furthermore, some very shallow concentrated earthquakes have occurred around the active Reclus and Burney volcanoes (Cisternas and Vera, 2008). 
The main geomorphological expression associated with the MFS is an 11m-high scarp developed in late Pleistocene-Holocene (?) deposits. This suggests that there have been other earthquakes responsible for this feature because the vertical slip of the 1949 event was less than $1 \mathrm{~m}$. Paleoseismic analysis of this fault indicates two, and possibly three pre-1949 paleoearthquakes preserved in the stratigraphy (Costa et al., 2006b).

More recent work by González-Bonorino et al (2012) found normal faults buried beneath gravelly strand plains on the Atlantic coast of Patagonia with displacement ages between 0.9 and $6.4 \mathrm{ka}$ and a recurrence rate of about $1 \mathrm{ka}$. Their most likely coseismic source is the MFS, more than $300 \mathrm{~km}$ distant, which suggests high-magnitude earthquake activity on this fault system throughout the Holocene.

\section{Discussion}

One of the main aims of this work is to address how the seismogenic potential of neotectonic faults in Chile can be estimated. We have examined the main parameters involved in determining the magnitude of an earthquake, including length, width and mean displacement of crustal faults. We compiled the characteristics of the most significant crustal faults regarding their morphotectonic imprint and characteristic rupture/displacement segments revealed by their surface trace. This study highlights the similarity of neotectonic fault parameters along and across different tectonic domains, with longitudinal segmentation being dominant.

Hence, we collected crustal fault parameters and recorded crustal earthquakes in the corresponding longitudinal domain, in order to gather all the necessary parameters to estimate Moment Magnitude and check the consistency of those estimations. Length of fault rupture and slip during an earthquake are the general parameters applied for earthquake magnitude estimations (Bonilla et al., 1984; Wells and Coppersmith, 1994; McCalpin, 2009). We applied one of the most commonly-used formulae developed after Hanks and Kanamori (1979):

$\mathrm{Mw}=2 / 3(\log$ Mo-9.1)

with $\mathrm{Mo}=\mu \mathrm{AD}$, where $\mu=$ shear modulus $(=30 \mathrm{GPa}$ in crust)

$\mathrm{A}=$ Length $*$ Width $=$ area

$\mathrm{D}=$ average displacement during rupture
Where the rupture plane is a $\mathrm{km}^{2}$ area with 1 order of magnitude range $(\mathrm{km}$ to tens of $\mathrm{km})$ and the average displacement ranges from centimeters to meters in scale, with, the latter parameter being the most sensitive to changes in the formulae.

This initial exercise constrains very well the order of magnitude of fault parameters, indicating which ones are key for the seismogenic hazard assessment.

\subsection{Fault parameters for longitudinal domains}

The seismogenic zone is where deformation processes are predominantly frictional and earthquakes can be nucleated and propagate as slip on preexisting fault surfaces or intact rock failure (Lockner and Beeler, 2002). The progressive transition from predominantly frictional deformation to a mainly quasi-plastic one, is commonly referred to as the base of this seismogenic zone or the brittle-plastic transition (e.g., Scholz, 1988; Sibson, 2002), and bounds the maximum possible depth for an earthquake in continental crust.

Crustal heterogeneities, coupled with variations in regional heat flow, account for much of the observed variation in the depth of the seismogenic zone (Sibson, 1984; Smith and Bruhn, 1984). The main parameters controlling crustal heterogeneity are plate rheology, thermal gradient, and elastic and crustal thickness. Fault zone rheology is strongly affected by the quartz/feldspar ratio: the temperature of the transitional zone can change from $\mathrm{T} \sim 350^{\circ} \mathrm{C}$ for quartz rich material to $\mathrm{T} \sim 450^{\circ} \mathrm{C}$ where feldspar is the dominant load-bearing constituent within the rock mass. Complexity at the base of the seismogenic zone, however, may be further compounded by fluid pressure cycling near the transition zone (Sibson, 1992, 1994).

Numerous studies evaluating and modelling subducting plate structures and geometries in the Andes have been performed since the general recognition of the subduction processes in the 1960s. Most models postulate a large, predominantly east-verging ramp detachment thrusting structure connecting the subduction zone with the cordillera throughout the Andes (e.g., Isacks, 1988; Farías et al., 2010; McQuarrie et al., 2005; Lamb, 2011, 2016; Armijo et al., 2015). These models depict a brittle and rigid forearc crust (high elastic thickness) and a weak ductile lower crust under the arc region (low elastic thickness), thus implying variable thicknesses 
of the brittle-ductile transition from the subduction trench to the Andes Cordillera.

By analyzing seismicity and surface geology in Central Chile, Farías et al. (2010) predict a brittle-ductile transition of less than $10 \mathrm{~km}$ under the Main Cordillera, at $\sim 25 \mathrm{~km}$ depth below the Central Depression and with the ramp detachment structure connecting with the subduction zone at $\sim 60$ $\mathrm{km}$ depth. Their results also suggest the presence of similar structures for northern and south-central Chile. It is important to highlight that the lower limit of crustal seismicity correlates well with the $400{ }^{\circ} \mathrm{C}$ isotherm (Fig. 4).

Arndt et al. (1997) suggest that the brittle-ductile transition occurs at depths of less than $20 \mathrm{~km}$ based on analysis of the thermal and elastic behavior of three granodioritic rocks from the Northern Chilean Coastal Cordillera. Ongoing thermal lithospheric modelling suggests that almost all of the crustal seismicity between 1996 and 2006 occurring at latitudes of $33^{\circ}-34^{\circ} \mathrm{S}$ is constrained in depth by the $350^{\circ} \mathrm{C}$ isotherm (Yáñez et al., personal communication, 2016). It follows that in the external forearc domain, earthquakes can be generated at any depth above the Benioff zone; from there to the arc, the isotherm shallows progressively from 30 to $15 \mathrm{~km}$ providing a rough estimate of the maximum depth for earthquake nucleation (Fig. 4). Accordingly, fault depth will increase away from the high heat flow domain of the volcanic arc and reach a maximum at the colder outer forearc region.

Our fault and earthquake data compilation reveals that the maximum known depths for crustal hypocenters are 25-30 km for the Outer Forearc domain, 15-20 km for Inner Forearc domain and 8-12 km for the Arc domain. Accordingly, the width of fault planes will depend on plane dip; subhorizontal faults could have bigger rupture areas, as it is on listric faults. Strike-slip faults, having almost vertical fault planes, will also share this limit.

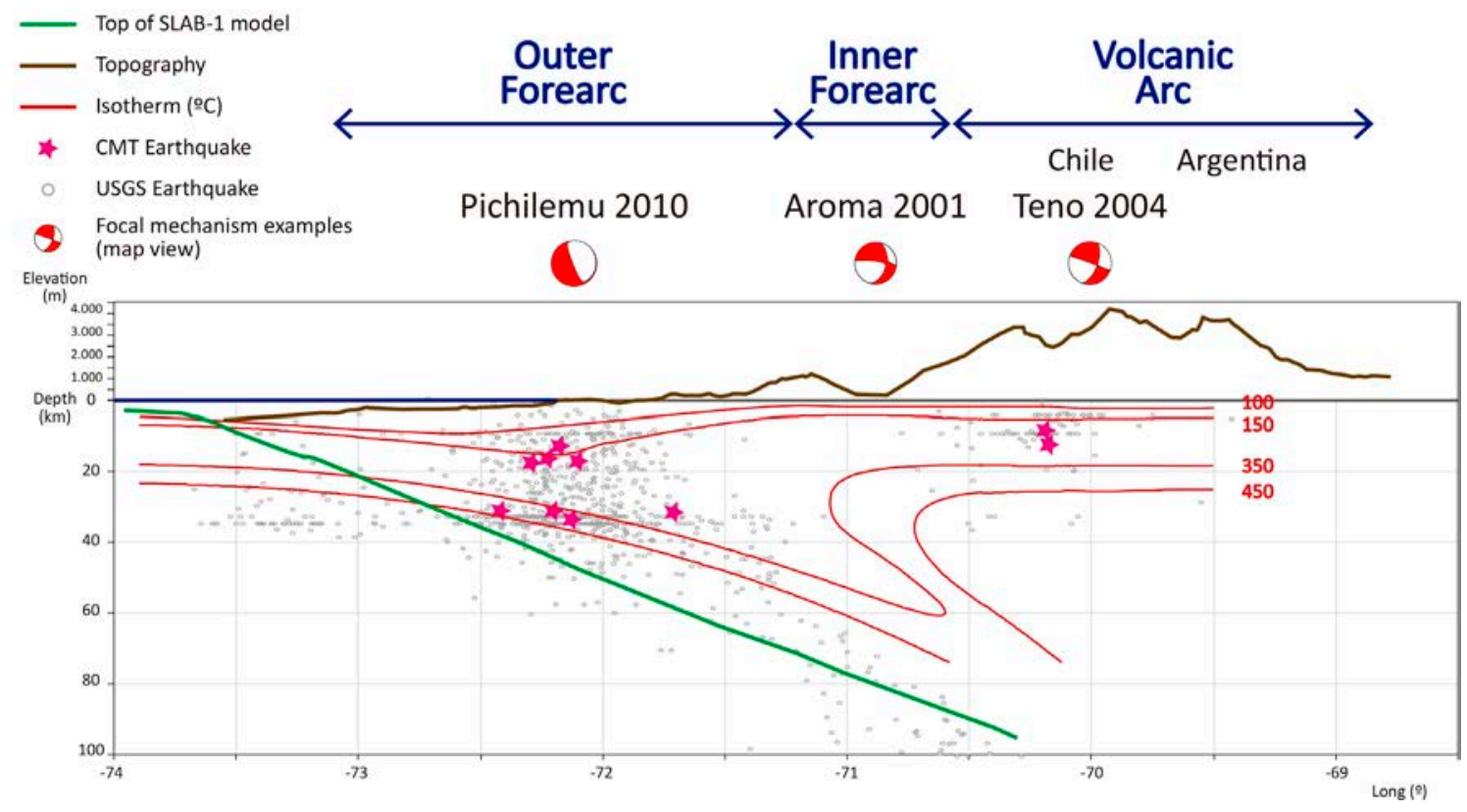

FIG. 4. Schematic cross section at central Chile latitude $\left(\sim 34^{\circ} \mathrm{S}\right)$ with studied earthquakes. Shown are the west to east domains and examples of crustal earthquakes with focal mechanisms for each domain. The Nazca-South American subduction zone is represented by the SLAB-1 model (Hayes et al., 2012) and the variable thicknesses, from the subduction trench to the Andes Cordillera, of the brittle-ductile transition on the South American plate is correlated with the generalized isothermal line $\sim 350^{\circ} \mathrm{C}$. The compiled crustal earthquakes located between $33.5^{\circ}$ and $34.5^{\circ} \mathrm{S}$ from CMT catalogue are highlighted (pink stars) from the totality of USGS (2018b) earthquakes in this range (grey circles in the background, 2018). Note crustal earthquake distribution across west to east domains, with greater crustal depths for outer forearc crustal events compared to inner forearc and the arc itself, augmenting the potential fault rupture area thus generating greater magnitude events. 
The length of fault planes was estimated from the geomorphic features of the numerous crustal faults along the Andean region. Fault segments of up to $40 \mathrm{~km}$ in length are easily identifiable in satellite images and Digital Elevation Models (DEM) for different fault systems or single fault traces. These fault traces are the result of several seismic events, superimposing their effects over thousands of years of slip in same and different segments of the fault. This repetition will most likely result in recognizable maximum-length segments for the involved period.

Two of the most difficult parameters to estimate are the fault slip rate and the accumulated net displacement controlling seismic momentum. Moreover, because fault slip is the most sensitive parameter in the earthquake magnitude equation, researchers should be cautious when assigning magnitudes to events with poorly estimated slip rates. From the few paleoseismological works which indicate discrete measurable event slips, and the dating of these events, slip rates and recurrence times were obtained (e.g., Cortés, 2012; Cortés et al., 2012; Vargas et al., 2014; González et al., 2015). These works suggest that maximum average displacements during earthquakes can generally reach up to $2 \mathrm{~m}$, or over $2 \mathrm{~m}$ in extraordinary cases.

By integrating studied faults, recorded earthquakes, morphotectonic and rheological features, we present a conceptualization of the main characteristics of Chilean crustal faults in table 3 . There we show an outline of where, how and by what distance a crustal fault could slip during a hazardous seismic event.

We conclude that the along-strike tectonic domains (longitudinal domains) are the most relevant for the seismogenic potential assessment of crustal faults in Chile, since it is more significant for the faults magnitude parameters.

\subsection{Estimated earthquakes}

Following the previous analysis, it is possible to estimate the maximum magnitude earthquake for each longitudinal domain, using scaling relationships (Stirling et al., 2013) and the assessed parameters seismogenic depth, length and slip, and assuming a constant shear modulus of $32 \mathrm{GPa}$ in the crust. These magnitude estimations are in complete agreement with the recorded seismic events for each domain (Table 3).

The earthquakes with the largest moment magnitudes ( $\mathrm{Mw} 7.5$ for normal and strike-slip faults to $\mathrm{Mw} 7.0$ reverse faults) occur in the Outer Forearc
Domain which experiences 0.2 to $0.6 \mathrm{~mm} / \mathrm{yr}$ of slip rate, with a recurrence time of a few thousand years. Events with magnitudes between 6.9 and 7.4 could occur in the Inner Forearc Domain, which experiences slip rates of 0.1 to $0.4 \mathrm{~mm} / \mathrm{yr}$ and recurrence times of a few thousand years. Events smaller than $\mathrm{Mw}$ 6.7 may occur in the Arc Domain, where the upper brittle crust thickness is lowest due to the presence of active magmatism. However, because slip rates of some arc domain faults are one order of magnitude higher than those of the outer and inner forearc domains, recurrence times could be as short as a few hundred years in this domain.

\subsection{Parameter uncertainties assessment}

The estimation, calculation or assessment of fault parameters is susceptible to errors, with the largest source being field data collection. The identification of recurrent rupture planes in the field (tectonic morphologies and/or deposits) becomes very difficult with the superposition of multiple seismic events, as previously mentioned. Consequently, the estimation of fault length for a characteristic earthquake or maximum credible earthquake is challenging and paleoseismological studies should be conducted along the entire length of a fault in order to be more fully representative and precise.

Fault displacement is also a difficult parameter to assess. For example, slip fault appraisal from colluvial wedge thickness formed coseismically in dip-slip faults: it must be identified a single seismic event colluvial wedge representative of an entire rupture zone slip. If all these conditions are found and the colluvial wedge had been under "normal" erosion rates, its height is thought to be half of the total slip as "rule of thumb" (McCalpin, 2009). But this relation must be used with caution, there are many problems in measuring 1 event-only colluvial wedges, scarp free-faces or displacement (e.g., Ostenaa, 1984; Nelson, 1992; McCalpin, 2009). However, even when all of this is considered, earthquake size is still commonly overestimated. The bigger range for average displacement with the common error percentage make this a key parameter.

\subsection{Activation mechanisms and hazard assessment}

Crustal faults are widely scattered across the entire length and breadth of the Andes. After analyzing fault 


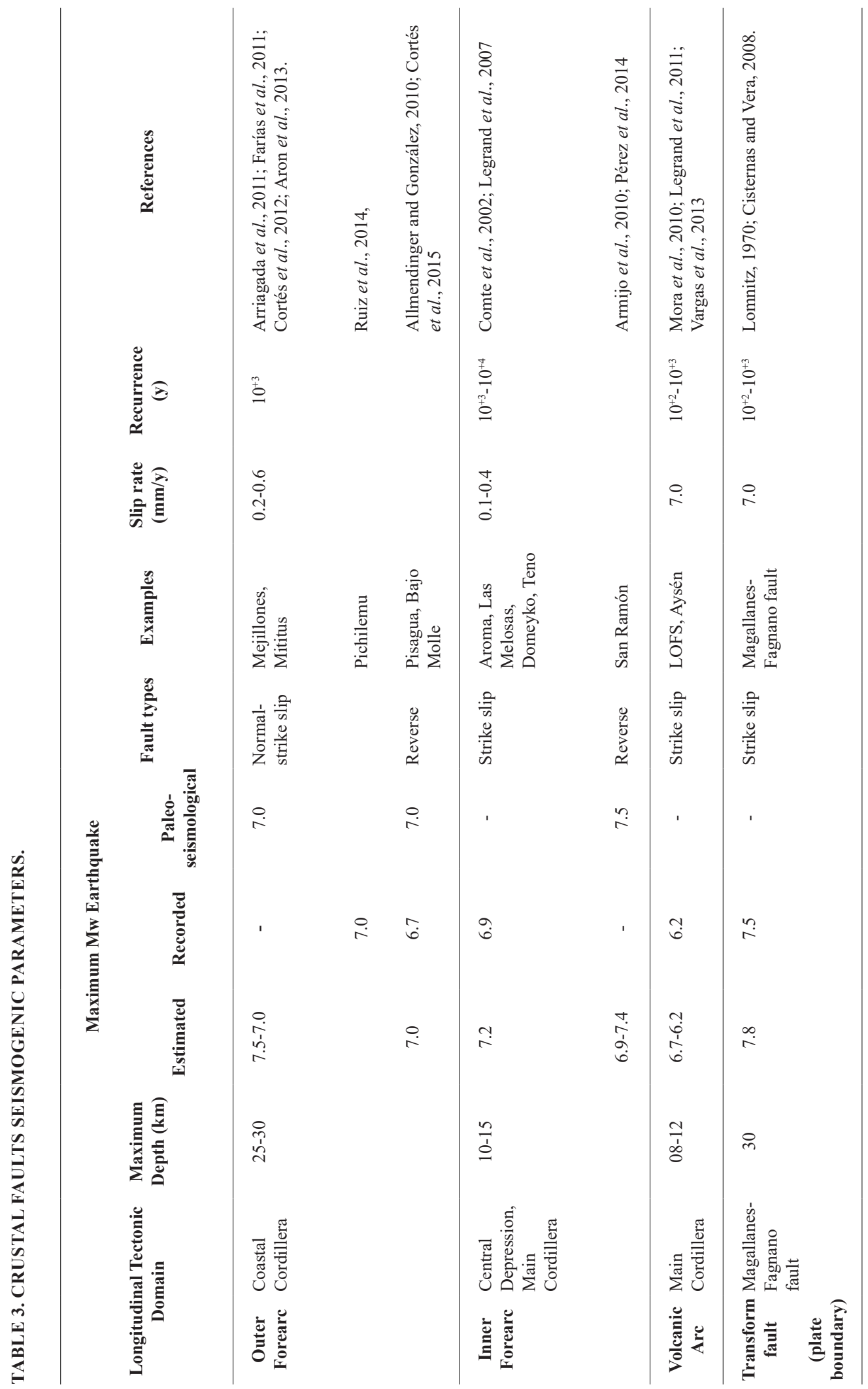


characteristics in their morphotectonic environment, it is possible to predict some seismogenic parameters for crustal faults located in particular tectonic domains. A summary of these conditions are shown in table 3 .

There is a strong documented correlation between crustal seismicity and large interplate earthquakes, acting in earthquake segmentation (e.g., EcuadorColombia, Collot et al., 2004; Alvarado et al., 2016; and Perú, Audin et al., 2008), slip partitioning (Melnick et al., 2006) or acting as mega-earthquake triggers (González et al., 2015) or coseismic/postseismic pseudo-aftershocks (Farías et al., 2011; Aron et al., 2013).

Outstanding examples in recent years in Chile are the Pichilemu and Iquique crustal earthquakes related to Maule 2010 and Iquique 2014 megathrust earthquakes respectively. The Pichilemu earthquakes Mw 7.0 and 6.9 (see section 4.5), 2 weeks after 2010 Maule earthquake, have been allegedly caused by the large change in Coulomb stress caused by the Maule earthquake (e.g., Farías et al., 2011; Aron et al., 2013). The other case is a Mw 6.7 reverse crustal earthquake which was apparently the trigger for the 2014 Iquique-Pisagua Mw 8.1 megathrust earthquake, also by creating a change in the stress conditions, as suggested by González et al. (2015). That work indicates that several other crustal earthquakes, with reverse and normal slip, took place before and after the intraplate earthquake.

Other crustal earthquake clusters were also temporally associated with the 1985 Valparaíso, 2007 Tocopilla and 2005 Antofagasta thrust earthquakes, with the amount of crustal earthquakes generally increasing in the period following these large earthquakes.

Normal faulting crustal earthquakes were also observed following the Tohoku 2011 (Mw 9.1) and Sumatra-Andaman 2004 (Mw 9.1) mainshocks (e.g., Dewey et al., 2007; Asano et al., 2011; Nettles et al., 2011; Hardebeck, 2012; Miyakawa and Otsubo, 2015). Toda et al. (2011a and 2011b) suggests that those faults were activated by static stress changes complementing local normal faulting regimes and stress heterogeneity. Hardebeck (2012) studied the rotations of the principal stress axes in those events, finding that they exhibit similar coseismic rotations; shallow plunge of $\sigma_{1}$ (maximum compressive stress axis) pre-event changing abruptly to $45^{\circ}$ plunge $\sigma_{1}$ and $\sigma_{3}$ (maximum and minimum compressive stress axes) immediately after. In that context, crustal faults can be oriented for either reverse or normal faulting in this post-mainshock stress field, depending on their dip, explaining the observed normal-faulting aftershocks. Hardebeck (2012) also states that the stress rotation outcome following these 3 earthquakes does not occur in all subduction earthquakes. Deeper earthquakes exhibit smaller coseismic stress rotations, likely due to increasing deviatoric stress with depth.

Farías et al. (2011) recommend that crustal faults, especially those in the outer forearc, should be considered for seismic hazard analysis despite the absence of historic seismic activity, because events such as the Pichilemu sequence after the Maule earthquake prove their seismogenic potential.

The seismogenic potential of crustal faults in Chile is fundamentally linked to the subduction earthquake cycle. For instance, optimally-oriented faults, regarding the deformation field and stress changes, may be reactivated at virtually any time (King et al., 1994; Stein et al., 1994; Stein, 1999; Kilb et al., 2000; Lin and Stein, 2004; Loveless et al., 2010; Seeber and Armbruster, 2000). This is particularly true for optimally-oriented ancient basement faults which are subjected to high strain rates, a condition which can be reached co-seismically with large subduction earthquakes, and the slip being partitioned with these faults (e.g., Melnick et al., 2006; Aron et al., 2013). In contrast, during the interseismic period, strain rates are kept relatively low making the reactivation of optimally oriented faults less likely. However, the precise nature of the link between crustal faults and the subduction zone earthquake cycle remains poorly understood.

We hypothesize that some crustal faults, especially those in the outer forearc, have the potential to reactivate co-seismically when optimally oriented with respect to the instantaneous extension direction arising from elastic rebound of mega-earthquakes (e.g., Pichilemu fault; Aron et al., 2013). Other faults may activate during the subduction interseismic period, including regional strike-slip faults and thrust faults in the main cordillera (e.g., Liquiñe-Ofqui fault, LOFS; Legrand et al., 2011; Mora et al., 2010).

\section{Conclusions}

The continental margin of the Chilean territory is segmented longitudinally into three tectonic domains -External Forearc, Inner Forearc and Volcanic Arcalong its length, which incorporate similar earthquake 
parameters as fault size, slip rate and earthquake magnitude for crustal faults, thus allowing for a first-order approach for seismic potential assessment.

Although sparse and limited, current structural, paleo-seismological and geodetic data suggests that slip rates in Chilean crustal faults range from $0.2 \mathrm{~mm} /$ $\mathrm{yr}$ in the forearc to up to $7.0 \mathrm{~mm} / \mathrm{yr}$ for the intra-arc. This implies recurrence times in the range of 200 to 50,000 years for $c a$. Mw 7 earthquakes.

Outer Forearc domain faults have the largest seismogenic potential, with earthquake magnitudes estimated at between $\mathrm{Mw} 7.0$ and $\mathrm{Mw} 7.5$, in agreement with recorded crustal earthquakes of $c a$. Mw 7.0 and similar magnitudes obtained from paleoseismological evidence. Slip rates range between 0.2 to $0.6 \mathrm{~mm} / \mathrm{yr}$ with recurrence times of several thousands of years for $c a$. Mw 7 earthquakes (Table 3).

Volcanic arc domain faults, by contrast, have the lowest estimated seismic potential with earthquake magnitudes of Mw 6.2 to 6.7. However, these faults have slip rates which are one order of magnitude greater than those of the Outer Forearc $(7.0 \mathrm{~mm} / \mathrm{yr})$ and have recurrence times of hundreds to thousands of years (Table 3 ).

The various different tectonic modes for reactivation of crustal faults in Chile -related to large interplate earthquakes and the stress field within the seismic cycle (section 6.4)- and their wide range of slip rates, greatly complicates the estimation of seismic hazard. Many structures considered active using traditional classification (see Machette, 2000 for a review) may not generate significant earthquakes in thousands of years according to their recurrence times, whereas other less-well-known faults, that have no instrumentally recorded seismicity, could trigger up to Mw 7 earthquakes. Furthermore, fault segments that have generated earthquakes independently from each other may be capable of merging into a single rupture zone and generate an earthquake of greater magnitude.

A rigorous seismic hazard assessment must then consider the different tectonic settings across the Chilean Andes, timing with interplate seismic cycle and slip rates of Andean crustal faults. Understanding the nature of these faults will help us not only to better assess the associated seismic hazard, but also to better understand and constrain their underlying connection with the subduction zone seismic cycle, as triggers, slip partitioning or result of subduction earthquakes.

\section{Acknowledgements}

This research was supported by Fondecyt Project 1140846, CIGIDEN, Fondap Project 15110017, Andes Fondef Project D10I1027 and Conicyt doctorate scholarship in Chile. We wish to thank P. Pérez, R. Gomila, J. CortésAranda, F. Leyton, F. Aron, R. Allmendinger, J. González, I. del Río, C. Rojas, P. Sánchez, P. Salazar, S. Rebolledo, G. Vargas, R. Saragoni, C. Mpodozis, L. Audin, R. Ridell, G. Montalva, and all the PUC Geosciences Group for the stimulating discussions about nature and significance of crustal faults and for the generous shared information. L. Acevedo kindly helped with figures. R. Wylie and J. Ruz helped with the english language check. Thorough and constructive reviews by Editor W. Vivallo and an anonymous reviewer significantly improved the quality of our manuscript.

\section{References}

Adriasola, A.C.; Thomson, S.N.; Brix, M.R.; Hervé, F.; Stockhert, B. 2006. Postmagmatic cooling and late Cenozoic denudation of the North Patagonian Batholith in the Los Lagos region of Chile, $41^{\circ}-42^{\circ} 15^{\prime} \mathrm{S}$. International Journal of Earth Sciences 95 (3): 504-528.

Agurto, H.; Rietbrock, A.; Barrientos, S.; Bataille, K.; Legrand, D. 2012. Seismotectonic structure of the Aysén Region, Southern Chile, inferred from the 2007 Mw=6.2 Aysén earthquake sequence. Geophysical Journal International 190: 116-130.

Agurto, H.; Rietbrock, A.; Bataille, K.; Miller, M.; Iwamori, H.; Priestley, K. 2014. Seismicity distribution in the vicinity of the Chile Triple Junction, Aysén Region, southern Chile. Journal of South American Earth Sciences 51: 1-11.

Aki, K.; Lee, W.H.K. 2003. Glossary of Interest to Earthquake and Engineering Seismologists. In International Handbook of Earthquake and Engineering Seismology, (Lee, W.H.K.; Kanamori, H.; Jennings, P.; Kisslinger, C.; editors). Academic Press 81B, Appendix 1: 1793 1856. London.

Alfaro, A. 2011. Peligro Sísmico en el Segmento Norte de la Región del Maule, Chile. Memoria de Título (Inédito), Universidad de Chile, Departamento de Geología: 136 p.

Allmendinger, R.W.; González, G. 2010. Invited review paper: Neogene to Quaternary tectonics of the coastal Cordillera, northern Chile. Tectonophysics 495 (1-2): 93-110.

Allmendinger, R.; González, G.; Yu, J.; Hoke, G.; Isacks, B. 2005. Trench-parallel shortening in the northern 
Chilean forearc: tectonic and climatic implications. Geological Society of America Bulletin 117: 89-104. Alvarado, A.; Audin, L.; Nocquet, J. M.; Lagreulet, S.; Segovia, M.; Font, Y.; Lamarque, G.; Yepes, H. Mothes, P.; Rolandone, F.; Jarrín, P.; Quidelleur, X. 2014. Active tectonics in Quito, Ecuador, assessed by geomorphological studies, GPS data, and crustal seismicity. Tectonics 33: 67-83.

Alvarado, A.; Audin, L.; Nocquet, J.M.; Jaillard, E.; Mothes, P.; Jarrín, P.; Segovia, M.; Rolandone, F.; Cisneros, D. 2016. Partitioning of oblique convergence in the Northern Andes subduction zone: Migration history and the present-day boundary of the North Andean Sliver in Ecuador. Tectonics 35 (5): 1048-1065.

Alvarado, P.; Barrientos, S.; Sáez, M.; Astroza, M.; Beck, S. 2009. Source study and tectonic implications of the historic 1958 Las Melosas crustal earthquake, Chile, compared to earthquake damage. Physics of the Earth and Planetary Interiors 175: 26-36.

Angermann, D.; Klotz, J.; Reigber, C. 1999. Space-geodetic estimation of the Nazca-South America Euler vector. Earth and Planetary Science Letters 171: 329-334.

Arabasz, W. J. 1971. Geological and geophysical studies of the Atacama Fault Zone in northern Chile. $\mathrm{Ph} . \mathrm{D}$. Thesis (Unpublished), California Institute of Technology: 264 p.

Armijo, R.; Rauld, R.; Thiele, R.; Vargas, G.; Campos, J.; Lacassin, R.; Kausel, E. 2010. The West Andean Thrust, the San Ramón Fault, and the seismic hazard for Santiago, Chile. Tectonics 29: 1-34.

Armijo, R.; Lacassin, R.; Coudurier-Curveur, A.; Carrizo, D. 2015. Coupled tectonic evolution of Andean orogeny and global climate. Earth-Science Reviews 143: 1-35.

Arndt, J.; Bartel, T.; Scheuber, E.; Schilling, F. 1997. Thermal and rheological properties of granodioritic rocks from the Central Andes, North Chile. Tectonophysics 271: $75-88$.

Aron, F.; Allmendinger, R.; Cembrano, J.; González, G.; Yáñez, G. 2013. Permanent fore-arc extension and seismic segmentation: Insights from the 2010 Maule earthquake, Chile. Journal of Geophysical Research, Solid Earth 118: 1-16.

Aron, F.; Cembrano, J.; Astudillo, F.; Allmendinger, R.; Arancibia, G. 2014. Constructing forearc architecture over megathrust seismic cycles: Geological snapshots from the Maule earthquake region, Chile. Geological Society of America Bulletin 127 (3-4): 464-479.

Arriagada, C.; Arancibia, G.; Cembrano, J.; Martínez, F.; Carrizo, D.; Van Sint Jan, M.; Sáez, E.; González, G.; Rebolledo, S.; Sepúlveda, S.A.; Contreras-Reyes,
E. Jensen, E.; Yáñez, G. 2011. Nature and tectonic significance of co-seismic structures associated with the Mw 8.8 Maule earthquake, central-southern Chile forearc. Journal of Structural Geology 33 (5): 891-897.

Asano, Y.; Saito, T.; Ito, Y.; Shiomi, K.; Hirose, H.; Matsumoto, T.; Aoi, S.; Hori, S.; Sekiguchi, S. 2011. Spatial distribution and focal mechanisms of aftershocks of the 2011 off the Pacific coast of Tohoku earthquake. Earth Planets Space 63 (7): 669-673.

Asch, G.; Schurr, B.; Bohm, M.; Yuan, X.; Haberland, C.; Heit, B.; Kind, R.; Woelbern, I.; Bataille, K.; Comte, D.; Pardo, M.; Viramonte, J.; Rietbrock, A.; Giese, P. 2006. Seismological Studies of the Central and Southern Andes. In The Andes-Active Subduction Orogeny. Frontiers in Earth Science Series Part II (Oncken, O.; Chong, G.; Franz, G.; Giese, P.; Götze, H-J.; Ramos, V.A.; Strecker, M.R.; Wigger, P.; editors). Springer-Verlag 21: 443-457. Berlin.

Audin, L.; Lacan, P.; Tavera, H.; Bondoux, F. 2008. Upper plate deformation and seismic barrier in front of Nazca subduction zone: The Chololo Fault System and active tectonics along the Coastal Cordillera, southern Peru. Tectonophysics 459 (1-4, 1): 174-185.

Bangs N.L.; Cande, S.C. 1997. Episodic development of a convergent margin inferred from structures and processes along the southern Chile margin. Tectonics 16: 489-503.

Barrientos, S. 1980. Regionalización sísmica de Chile. Tesis de Magíster en Ciencias (Inédito). Universidad de Chile, Departamento de Geofísica: 72 p.

Barrientos, S.E.; Ward, S.N. 1990. The 1960 Chile earthquake: inversion for slip distribution from surface deformation. Geophysical Journal International 103 (3): 589-598.

Barrientos, S.; Vera, E.; Alvarado, P.; Monfret, T. 2004. Crustal seismicity in central Chile. Journal of South American Earth Sciences 16: 759-768.

Barrientos, S. 2007. Earthquakes in Chile. In The Geology of Chile (Moreno, T.; Gibbons, W.; editors). Geological Society: 263-287. London.

Bloch, W.; Kummerow, J.; Salazar, P.; Wigger, P.; Shapiro, S.A. 2014. High-resolution image of the North Chilean subduction zone: seismicity, reflectivity and fluids. Geophysical Journal International 197: 1744-1749.

Bondar, I.; Engdahl, E.R.; Villaseñor, A.; Harris, J.; Storchak, D. 2015. ISC-GEM: Global Instrumental Earthquake Catalogue (1900-2009), II. Location and seismicity patterns. Physics of the Earth and Planetary Interiors 239: 2-13. 
Bonilla, M.C.; Mark; R.X.; Lienkaemper, J.J. 1984. Statistical relations among earthquake magnitude, surface rupture length, and surface fault displacement. Bulletin of the Seismological Society of America 74: 2379-2422.

Brown, M.; Díaz, F.; Grocott, J. 1993. Displacement history of the Atacama fault system $25^{\circ} 00^{\prime}-27^{\circ} 00^{\prime} \mathrm{S}$, northern Chile. Geological Society of America Bulletin 105: 1165-1174.

Burbank, D.; Anderson, R. 2001. Tectonic Geomorphology. Blackwell Science Ltd.: 274 p. Oxford.

Campos, J.; Kausel, E. 1990. The large 1939 intraplate earthquake of southern Chile. Seismological Research Letters 61: p. 43.

Cande, S.C.; Leslie, R.B. 1986. Late Cenozoic tectonics of the southern Chile Trench. Journal of Geophysical Research 91: 471-496.

Carrizo, D.; González, G.; Dunai, T. 2008. Constricción neógena en la Cordillera de la Costa, norte de Chile: Neotectónica y datación de superficies con ${ }^{21} \mathrm{Ne}$ cosmogénico. Revista Geológica de Chile 35 (1): 1-38. doi: 10.5027/andgeoV35n1-a01.

Cembrano, J.; Hervé, F. 1993. The Liquiñe Ofqui Fault Zone: a major Cenozoic strike slip duplex in the Southern Andes. In International Symposium on Andean Geodynamics, No 2, ISAG: 175-178. Oxford.

Cembrano, J.; Moreno, H. 1994. Geometría y naturaleza contrastante del volcanismo cuaternario entre los $38^{\circ}$ y $46^{\circ} \mathrm{S}$ : Dominios compresionales y tensionales en un régimen transcurrente? In Actas Congreso Geológico Chileno, No. 7: 240-244. Concepción.

Cembrano, J.; Lara, L. 2009. The link between volcanism and tectonics in the Southern Volcanic Zone of the Chilean Andes: A review. Tectonophysics 471 (1-2): 96-113.

Cembrano, J.; Hervé, F.; Lavenu, A. 1996. The LiquiñeOfqui fault zone: a long-lived intra-arc fault Zone in southern Chile. Tectonophysics 259: 55-66.

Cembrano, J.; Lavenu, A.; Reynolds, P.; Arancibia, G.; Lopez, G.; Sanhueza, A. 2002. Late Cenozoic transpressional ductile deformation north of the Nazca-South America-Antarctica triple junction. Tectonophysics 354: 289-314.

Cembrano, J.; González, G.; Arancibia, G.; Ahumada, I.; Olivares, V.; Herrera, V. 2005. Fault zone development and strain partitioning in an extensional strike-slip duplex: A case study from the Mesozoic Atacama fault system, northern Chile. Tectonophysics 400 (1-4): 105-125.
Cembrano, J.; Lavenu, A.; Yáñez, G.; Riquelme, R.; García, M.; González, G.; Hérail, G. 2007. Neotectonics. In The Geology of Chile (Moreno, T.; Gibbons, W.; editors). Geological Society: 263-287. London.

Chernicoff, C.J.; Richards, J.P.; Zappettini, E.O. 2002. Crustal lineament control on magmatism and mineralization in northwestern Argentina: geological, geophysical, and remote sensing evidence. Ore Geology Reviews 21: $127-155$.

Chiou, B.S.J.; Youngs, R.R. 2014. Update of the Chiou and Youngs NGA Ground Motion Model for Average Horizontal Component of Peak Ground Motion and Response Spectra. Earthquake Spectra 30: 1117-1153.

Cifuentes, I.L. 1989. The 1960 Chilean earthquakes. Journal of Geophysical Research 94 (B1): 665-680.

Cisternas, A.; Vera, E. 2008. Sismos históricos y recientes en Magallanes. Magallania 36 (1): 43-51.

Cisternas, M.; Atwater, B.F.; Torrejón, F.; Sawai, Y.; Machuca, G.; Lagos, M.; Eipert, A.; Youlton, C.; Salgado, I.; Kamataki, T.; Shishikura, M.; Rajendran, C.P.; Malik, J.K.; Rizal, Y.; Husni, M. 2005. Predecessors of the giant 1960 Chile earthquake. Nature 437: 404-407.

Civile, D.; Lodolo, E.; Vuan, A.; Loreto, M.F. 2012. Tectonics of the Scotia-Antarctica plate boundary constrained from seismic and seismological data. Tectonophysics 550-553: 17-34.

Collot, J.Y.; Marcaillou, B.; Sage, F.; Michaud, F.; Agudelo, W.; Charvis, P.; Graindorge, D.; Gutscher, M-A.; Spence, G. 2004. Are rupture zone limits of great subduction earthquakes controlled by upper plate structures? Evidence from multichannel seismic reflection data acquired across the northern Ecuadorsouthwest Colombia margin. Journal of Geophysical Research 109: B11103.

Comte, D.; Eisenberg, A.; Lorca, E.; Pardo, M.; Ponce, L.; Saragoni, R.; Singh, S.K.Y.; Suárez, G. 1986. The 1985 Central Chile Earthquake: A Repeat of Previous Great Earthquakes in the Region? Science 233 (4762): 449-453.

Comte, D.; Bordier, M.; Boroschek, R.; David, C.; Martinod, J.; Glass, B.; Correa, E.; Balmaceda, I.; Dorbath, L.; Haessler, H.; Herail, G.; Meneses, C.; Frogneux, M.; Cruz, A. 2001. Analysis of the 24 July 2001 shallow earthquake $\mathrm{Mw}=6.3$ recorded in the Northern Chile Altiplano. In Eos, Transactions American Geophysical Union, Fall Meeting 82 (47) Abstract: S52A-0616.

Comte, D.; Dorbath, L.; Pardo, M.; Monfret, T.; Haessler, H.; Rivera, L.; Frogneux, M.; Glass, B.; Meneses, C. 2002. Análisis del terremoto superficial del Altiplano, norte de Chile, ocurrido el 24 de julio de 2001, Mw=6.3. 
In Jornadas Chilenas de Sismología e Ingeniería Antisísmica, No. 8: 8 p. Valparaíso.

Comte, D.; Farías, M.; Charrier, R.; González, A. 2008. Active Tectonics in the Central Andes: 3D tomography based on the aftershock sequence of the 28 August 2004 shallow crustal earthquake. In International Symposium on Andean Geodynamics, No. 7, ISAG: 160-163. Nice.

Cornejo, P.; Tosdal, R.M.; Mpodozis, C.; Tomlinson, A.; Rivera, O.; Fanning, M.C. 1997. El Salvador, Chile, porphyry copper deposit revisited: Geologic and geochronologic framework. International Geology Review 39: 22-54.

Cortés, J.A. 2012. Actividad de fallas de la placa superior en el antearco costero del norte de Chile ( $\left.23^{\circ} 30^{\prime} S\right)$ : Paleosismología, implicancias neotectónicas y relación con el ciclo de subducción. Ph.D. Thesis (Unpublished), Universidad Católica del Norte-Université Paul Sabatier Toulouse 3: $346 \mathrm{p}$.

Cortés, J.A.; González, G.; Binnie, S.A.; Ruth, R.; Freeman, S.P.H.T.; Vargas, G. 2012. Paleoseismology of the Mejillones Fault, northern Chile: Insights from cosmogenic ${ }^{10} \mathrm{Be}$ and Optically Stimulated Luminescence determinations. Tectonics 31 (2). doi: 10.1029/2011TC002877.

Cortés-Aranda. J.; González. G.; Remy. D.; Martinod, J. 2015. Normal upper plate fault reactivation in northern Chile and the subduction earthquake cycle: From geological observations and static Coulomb Failure Stress (CFS) change. Tectonophysics 639: 118-131.

Costa, C. 2004. Microtectónica en el Cuaternario? Métodos y aplicaciones de la Paleosismología. Revista Asociación Geológica Argentina, Publicación Especial 7: 9-19.

Costa, C.H.; Audemard, F.A.; Bezerra, F.H.R.; Lavenu, A.; Machette, M.N.; París, G. 2006a. An overview of the main Quaternary deformation of South America. Revista de la Asociación Geológica Argentina 61 (4): 461-479.

Costa, C.; Smalley, R.; Schwartz, D.; Stenner, H.; Ellis, M.; Ahumada, E.; Velasco, M. 2006b. Paleoseismic observations of an onshore transform boundary: The Magallanes-Fagnano fault, Tierra del Fuego, Argentina. Revista de la Asociación Geológica Argentina 61 (4): 647-657.

Costa, C.; Audemard, F.; Audin, L.; Benavente, C. 2010. Geomorphology as a Tool for Analysis of Seismogenic Sources in Latin America and the Caribbean. In Natural Hazards and Human-Exacerbated Disasters in Latin America. Special Volumes of Geomorphology.
Developments in Earth Surface Processes (Latrubesse, E.; editor). Elsevier 13: 29-47. Amsterdam.

David, C. 2007. Comportamiento actual del ante-arco y del arco del codo de Arica en la orogénesis de los Andes centrales. Ph.D. Thesis (Unpublished), Universidad de Chile-Université Paul Sabatier: 291 p.

David, C.; Martinod, J.; Comte, D.; Haessler, H.; Dorbath, L. 2002. Intracontinental Seismicity and Neogene Deformation of the Andean Forearc in the region of Arica $\left(18,5^{\circ}-19,5^{\circ} \mathrm{S}\right)$. In International Symposium on Andean Geodynamics, No. 5, ISAG: 171-174. Toulouse.

DeLouis, B.; Philip, H.; Dorbath, L. Cisternas, A. 1998. Recent crustal deformation in the Antofagasta Region (northern Chile) and the subduction process. Geophysical Journal International 132: 302-338.

DeMets, C.; Gordon, R.G.; Argus, D.F.; Stein, S. 1990. Current plate motions. Geophysical Journal International 10: 425-478.

DeMets, C.; Gordon, R.G.; Argus, F.; Stein, S. 1994. Effect of recent revisions of the geomagnetic timescale on estimates of current plate motions. Geophysical Research Letters 21: 2191-2194.

DeMets, C.; Gordon, R.G.; Argus, D.F. 2010. Geologically current plate motions. Geophysical Journal International 181: 1-80.

Dewey, J.W.; Choy, G.; Presgrave, B.; Sipkin, S.; Tarr, A.C.; Benz, H.; Earle, P.; Wald, D. 2007. Seismicity associated with the Sumatra-Andaman Islands earthquake of 26 December 2004. Bulletin of the Seismological Society of America 97(1A): S25-S42.

Dunai, T.J.; González López, G.A.; Juez-Larré, J. 2005, Oligocene-Miocene age of aridity in the Atacama Desert revealed by exposure dating of erosion-sensitive landforms. Geology 33: 321-324.

Espinoza, R. 2013. Sistemas de fallas Caleta Herradura: Evolución, Cinemática y Geometría. Península de Mejillones, Norte de Chile. Memoria de Título (Inédito). Universidad Católica del Norte.

Estay, N.P.; Yáñez, G.; Carretier, S.; Lira, E.; Maringue, J. 2016. Seismic hazard in low slip rate crustal faults, estimating the characteristic event and the most hazardous zone: study case San Ramón fault, in central Andes. Natural Hazards Earth System Sciences 16: 2511-2528.

Fairbridge, R. 1981. The concept of neotectonics: An introduction. Zeitschrift Geomorphologischen Beilband 40: 7-12.

Farías, M. 2007. Tectónica y erosión en la evolución del relieve de los Andes de Chile Central durante el Neógeno. Tesis de Ph.D. (Inédito), Universidad de Chile, Departamento de Geología: 191 p. 
Farías, M.; Charier, R.; Comte, D.; Martinod, J.; Hérail, G. 2005. Late Cenozoic deformation and uplift of the western flank of the Altiplano: Evidence from the depositional, tectonic, and geomorphologic evolution and shallow seismic activity (northern Chile at $19^{\circ} 30^{\prime} \mathrm{S}$ ). Tectonics 24: TC4001.

Farías, M.; Comte, D.; Charrier, R.; Martinod, J.; David, C.; Tassara, A.; Tapia, F.; Fock, A. 2010. Crustalscale structural architecture in central Chile based on seismicity and surface geology: implications for Andean mountain building. Tectonics 29 (3): TC3006.

Farías, M.; Comte, D.; Roecker, S.; Carrizo, D.; Pardo, M. 2011. Crustal extensional faulting triggered by the 2010 Chilean earthquake: The Pichilemu Seismic Sequence. Tectonics 30: TC6010.

Fock, A. 2005. Cronología y tectónica de la exhumación en el neógeno de los Andes de Chile central entre los $33^{\circ}$ y los $34^{\circ} \mathrm{S}$. Tesis de Magister (Inédito), Universidad de Chile: 235 p.

Forsythe, R.D.; Nelson, E. 1985. Geological manifestation of ridge collision: Evidence for the Golfo de Penas, Taitao basin, southern Chile. Tectonics 4: 477-495.

Gerbault, M.; Cembrano, J.; Mpodozis, C.; Farías, M.; Pardo, M. 2009. Continental margin deformation along the Andean subduction zone: Thermo-mechanical models. Physics of the Earth and Planetary Interiors 177: 180-205.

González-Bonorino, G.; Rinaldi, V.; del Valle, L.; Alvarado, P.; Bujalesky, G.G.; Güell, A. 2012. Paleoseismicity and seismic hazard in southern Patagonia (ArgentinaChile; 50-55S) and the role of the Magallanes-Fagnano transform fault. Natural Hazards 61: 337-349.

González, A. 2008. Análisis estructural entre los valles del río Tinguiririca y Teno, Cordillera Principal de Chile Central: Microsismicidad y Geología Superficial. Memoria de Título (Inédito), Universidad de Chile: 90 p.

González, G.; Cembrano, J.; Carrizo, D.; Macci, A.; Schneider, H. 2003. Link between forearc tectonics and Pliocene-Quaternary deformation of the Coastal Cordillera, Northern Chile. Journal of South American Earth Sciences 16: 321-342.

González, G.; Dunai, T.; Carrizo, D.; Allmendinger, R. 2006. Young displacements on the Atacama Fault System, northern Chile from field observations and cosmogenic ${ }^{21} \mathrm{Ne}$ concentrations. Tectonics 25 : TC3006.

González, G.; Gerbault, M.; Martinod, J.; Cembrano, J.; Allmendinger, R.; Carrizo, D.; Espina, J. 2008. Crack formation on top of propagating reverse faults of the Chuculay Fault System northern Chile: insights from field data and numerical modeling. Journal of Structural Geology 30: 791-808.

González, G.; Salazar, P.; Loveless, J.P.; Allmendinger, R.W.; Aron, F.; Shrivastava, M. 2015. Upper plate reverse fault reactivation and the unclamping of the megathrust during the 2014 northern Chile earthquake sequence. Geology 43 (8): 671-674. doi: 10.1130/G36703.1.

Grant, L. 2002. Paleoseismology. In International Handbook of Earthquake and Engineering Seismology, (Lee, W.H.K.; Kanamori, H.; Jennings, P.; Kisslinger, C.; editors). Academic Press 81A (30): 475-489. London.

Gutscher, M.; Spakman, W.; Bijwaard, H.; Engdahl, E. 2000. Geodynamics of flat subduction: seismicity and tomographic constraints from the Andean margin. Tectonics 19: 814-833.

Haberland, C.; Rietbrock, A.; Lange, D.; Bataille, K.; Hofmann, S. 2006. Interaction between forearc and oceanic plate at the south-central Chilean margin as seen in local seismic data. Geophysical Research Letters 33: 1-5.

Hampel, A.; Kukowski, N.; Bialas, J. 2004. Ridge subduction at an erosive margin: the collision zone of the Nazca Ridge in southern Peru. Journal of Geophysical Research 109: B02101.

Hancock, P. 1988. Neotectonics. Geology Today 4: 57-61.

Hancock, P.L.; Williams, G.D. 1986. Neotectonics. Journal of the Geological Society 143 (2): 325-326.

Hanks, T.C.; Kanamori, H. 1979. A Moment Magnitude Scale. Journal of Geophysical Research 84: 2348-2350.

Hanks, T.C.; Bakun, W.H. 2008. M-logA Observations for Recent Large Earthquakes. Bulletin of the Seismological Society of America 98: 490-494.

Hardebeck, J.L. 2012. Coseismic and postseismic stress rotations due to great subduction zone earthquakes. Geophysical Research Letters 39: L21313.

Hayes, G.P.; Wald, D.J.; Johnson, R.L. 2012. Slab1.0: A three-dimensional model of global subduction zone geometries. Journal of Geophysical Research 117: B01302.

Hervé, F.; Araya, E.; Fuenzalida, J.L.; Solano, A. 1979. Edades radiométricas y tectónica neógena en el sector costero de Chiloé continental, X Región. In Congreso Geológico Chileno, No. 2: FI-F8. Arica.

Hervé, M. 1976. Estudio geológico de la falla LiquiñeReloncaví en el área de Liquiñe; antecedentes de un movimiento transcurrente (Provincia de Valdivia). In Congreso Geológico Chileno, No. 1: B39-B56. Santiago.

Hervé, M. 1987. Movimiento normal de la falla Paposo, Zona de Falla de Atacama, en el Mioceno, Chile. 
Revista Geológica de Chile 31: 31-36. doi: 10.5027/ andgeoV14n2-a04.

Hoffmann-Rothe, A.; Kukowski, N.; Dresen, G.; Echtler, H.; Oncken, O.; Klotz, J.; Scheuber, E.; Kellner, A. 2006. Oblique convergence along the Chilean margin: partitioning, margin-parallel faulting and force interaction at the plate interface. In The AndesActive Subduction Orogeny. Frontiers in Earth Science Series Part II (Oncken, O.; Chong, G.; Franz, G.; Giese, P.; Götze, H-J.; Ramos, V.A.; Strecker, M.R.; Wigger, P.; editors). Springer-Verlag (6): 125-146. Berlin.

Hoke, G.D. 2006. The influence of climate and tectonics on the geomorphology of the western slope of the Central Andes, Chile and Peru. Ph.D. Thesis (Unpublished), Cornell University: 283 p.

Isacks, B.L. 1988. Uplift of the central Andean plateau and bending of the Bolivian orocline. Journal of Geophysical Research 93 (B4): 3211-3231.

Isacks, B.; Barazangi, M. 1977. Geometry of Benioff zones: lateral segmentation and downwards bending of the subducted lithosphere. In Island Arcs, Deep Sea Trenches and Back Arc Basins (Talwani, M.; Pitman, W.; editors). American Geophysical Union, Ewing Series (1): 99-114. Washington.

Iturrieta, P.C.; Hurtado, D.E.; Cembrano, J.; StantonYonge, A. 2017. States of stress and slip partitioning in a continental scale strike-slip duplex: Tectonic and magmatic implications by means of finite element modeling. Earth and Planetary Science Letters 473: 71-82.

Jarrard, R.D. 1986. Relations among subduction parameters. Reviews of Geophysics 24 (2): 217-284.

Jordan, T.E.; Isacks, B.L.; Allmendinger, R.W.; Brewer, J.A.; Ramos, V.A.; Ando, C.J. 1983a. Andean tectonics related to geometry of subducted Nazca plate. GSA Bulletin 94: 341-361.

Jordan, T.E.; Isacks, B.L.; Ramos, V.; Allmendinger, R. W. 1983b. Mountain building in the Central Andes. Episodes 3: 20-26.

Jordan, T.E.; Burns, W.M.; Veiga, R.; Pangaro, F.; Copeland, P.; Kelley, S.; Mpodozis, C. 2001. Extension and basin formation in the southern Andes caused by increases convergence rate: a Mid-Cenozoic trigger for the Andes. Tectonics 20: 308-324.

Jordan, T.E.; Kirk-Lawlor, N.; Blanco, N.; Nester, P.; Rech, J. 2014, Landscape modification in response to repeated onset of hyperarid paleoclimate states since $14 \mathrm{Ma}$, Atacama Desert, Chile. Geological Society of America Bulletin 126: B30978-B30971.
Kagan, Y. 1993. Statistics of characteristic earthquakes. Bulletin of the Seismological Society of America 83: 7-24.

Kagan, Y. 2002. Seismic moment distribution revisited: I. Statistical results. Geophysical Journal International 148: 520-541.

Kilb, D.; Gomberg, J.; Bodin, P. 2000. Triggering of earthquake aftershocks by dynamic stresses. Nature 408: 570-574.

King, G.C.P.; Stein, R.S.; Lin, J. 1994. Static stress changes and the triggering of earthquakes. Bulletin of the Seismological Society of America 84 (3): 935-953.

Kley, J.; Monaldi, C.R.; Salfity, J.A.; 1999. Along-strike segmentation of the Andean foreland: causes and consequences. Tectonophysics 301: 75-94.

Kober, F.; Ivy-Ochs, S.; Schlunegger, F.; Baur, H.; Kubik, P.W.; Wieler, R. 2007. Denudation rates and a topography-driven rainfall threshold in northern Chile: Multiple cosmogenic nuclide data and sediment yield budgets. Geomorphology 83: 97-120.

Lamb, S. 2011. Did shortening in thick crust cause rapid Late Cenozoic uplift in the northern Bolivian Andes? Journal of the Geological Society 168 (5): 1079-1092.

Lamb, S. 2016. Cenozoic uplift of the Central Andes in northern Chile and Bolivia-reconciling paleoaltimetry with the geological evolution. Canadian Journal of Earth Sciences 53: 1227-1245.

Lamb, S.; Davis, P. 2003. Cenozoic climate change as a possible cause for the rise of the Andes. Nature 425: 792-797.

Lange, D.; Cembrano, J.; Rietbrock, A.; Haberland, C.; Dahm, T.; Bataille, K. 2008. First seismic record for intra-arc strike-slip tectonics along the Liquiñe-Ofqui fault zone at the obliquely convergent plate margin of the southern Andes. Tectonophysics 455: 14-24.

Lara, L.; Naranjo, J.; Moreno, H. 2004. Rhyodacitic fissure eruption in Southern Andes (Cordón Caulle; $40.5^{\circ} \mathrm{S}$ ) after the 1960 (Mw: 9.5) Chilean earthquake: a structural interpretation. Journal of Volcanology and Geothermal Research 138: 127-138.

Lara, L.; Lavenu, A.; Cembrano, J.; Rodríguez, C. 2006. Structural controls of volcanism in transversal chains: resheared faults and neotectonics in the Cordón CaullePuyehue area $\left(40.5^{\circ} \mathrm{S}\right)$, Southern Andes. Journal of Volcanology and Geothermal Research 158: 70-86.

Lavenu, A. 2005. Fallas Cuaternarias de Chile. Servicio Nacional de Geología y Minería, Boletín 62: 71 p. Santiago.

Lavenu, A.; Cembrano, J. 1999. Compressional and transpressional-stress pattern for Pliocene and 
quaternary brittle deformation in fore arc and intra-arc zones (Andes of central and southern Chile). Journal of Structural Geology 21: 1669-1691.

Lavenu, A.; Thiele, R.; Machette, M.; Dart, R.; Bradley, L.-A.; Haller, K. 2000. Maps and database of quaternary faults in Bolivia and Chile. USGS Open File Report 00-283: 46p.

Legrand, D.; Delouis, B.; Dorbath, L.; David, C.; Campos, J.; Márquez, L.; Thompson, J.; Comte, D. 2007. Source parameters of the $\mathrm{Mw}=6.3$ Aroma crustal earthquake of July 24, 2001 (northern Chile), and its aftershock sequence. Journal of South American Earth Sciences 24: 58-68.

Legrand, D.; S. Barrientos, K. Bataille, J. Cembrano, J. 2011. The fluid-driven tectonic swarm of Fjordo Aysen, Chile (2007) associated with two earthquakes $(\mathrm{Mw}=6.1$ and $\mathrm{Mw}=6.2)$ within the Liquiñe-Ofqui Fault Zone. Continental Shelf Research 31 (3-4): 154-161.

Leyton, F.; Ruiz, S.; Sepúlveda, S. 2010. Reevaluación del peligro sísmico probabilístico en Chile Central. Andean Geology 37 (2): 455-472. doi: 10.5027/ andgeoV37n2-a11.

Li, Y-G.; De Pascale, G.; Quigley, M.; Gravley, D. 2014. Fault damage zones of the M7.1 Darfield and M6.3 Christchurch earthquakes characterized by fault-zone trapped waves. Tectonophysics 618: 79-101

Lin, J.; Stein, R.S. 2004. Stress triggering in thrust and subduction earthquakes and stress interaction between the southern San Andreas and nearby thrust and strike-slip faults. Journal of Geophysical Research 109: B02303.

Lindquist, K.G.; Engle, K.; Stahlke, D.; Price, E. 2004. Global topography and bathymetry grid improves research efforts. EOS 85 (19): p. 186. doi: 10.1029/2004EO190003.

Lindsay, D.; Zentilli, M.; Rivera, A. 1995. Evolution of an active ductile to brittle shear system controlling mineralization at Chuquicamata porphyry copper deposit, northern Chile. International Geology Review 37: 945-958.

Lockner, D.A.; Beeler, N.M. 2002. Rock Failure and Earthquakes. In International Handbook of Earthquake and Engineering Seismology (Lee, W.H.K.; Kanamori, H.; Jennings, P.; Kisslinger, C.; editors). Academic Press 81A (32): 505-538. London.

Lodolo, E.; Menichetti, M.; Tassone, A.; Geletti, R.; Sterzai, P.; Lippai, H.; Hormaechea, H.L. 2002. Researchers target a continental transform fault in Tierra del Fuego. Eos, Transactions American Geophysical Union 83: 5-61.

Lodolo, E.; Menichetti, M.; Bartole, R.; Ben-Avraham, Z.; Tassone, A.; Lippai, H. 2003. Magallanes-Fagnano continental transform fault (Tierra del Fuego, southernmost South America). Tectonics 22 (6): 28 p. doi: 10.1029/2003TC001500.

Lomnitz, C. 1960. A study of the Maipo Valley earthquakes of September 4, 1958. Instituto de Geofísica y Sismología, Universidad de Chile, Publication No. 10: p.

Lomnitz, C. 1970. Major earthquakes and tsunamis in Chile during the period 1535 to 1955 . Geologische Rundschau 59: 938-960.

Lomnitz, C. 2004. Major earthquakes of Chile: A historical survey, 1535-1960. Seismology Research Letters 75: 368-378.

Loveless, J.P.; Allmendinger, R.W.; Pritchard, M.E.; González, G. 2010. Normal and reverse faulting driven by the subduction zone earthquake cycle in the northern Chilean fore arc: Tectonics 29: TC2001.

Machare, J.; Ortlieb, L. 1992. Plio-Quaternary vertical motions and the subduction of the Nazca Ridge, central coast of Peru. Tectonophysics 205 (1-3): 97-108.

Machare, J.; Fenton, C.; Machette, M.N.; Levenu, A.; Costa, C.; Dart, R. 2003. Database and map of Quaternary faults and folds in Peru and its offshore region, U.S. Geological Survey Open File Report 03-451. International Lithosphere Program's Task Group II-2 "World Map of Major Active Faults." accompanied by database http://pubs.usgs.gov/of/2000/ofr-03-451/ (last visit 28-11-2018).

Machette, M. 2000. Active, Capable and Potentially Active Faults- A paleoseismic perspective. Journal of Geodynamics 29: 387-392.

Marquardt, C. 2005. Deformations Néogènes le long de la Côte Nord du Chile $\left(23^{\circ}-27^{\circ} \mathrm{S}\right)$, avant-arc des Andes Centrales. Ph.D. Thesis (Unpublished), Universite Toulouse III Paul Sabatier: 212 p.

Marquardt C.; Lavenu, A.; Ortlieb, L.; Godoy, E.; Comte, D. 2004. Coastal Neotectonics in Southern Central Andes: Uplift Rates and Strain Patterns in the Caldera Area, Northern Chile $\left(27^{\circ} \mathrm{S}\right)$. Tectonophysics 394 (3-4): 193-219.

Masana, E.; Santanach, P.; Pallás, R.; Calvet, J.; Chong, G. 2005. Active tectonics and kinematics of the Chomache fault (Salar Grande, northern Chile). In International Symposium on Andean Geodynamics, No. 6, ISAG: 493-496. Barcelona.

Matmon, A.; Simhai, O.; Amit, R.; Haviv, I.; Porat, N.; Mc-Donald, E.; Benedetti, L.; Finkel, R. 2009, Desert pavement-coated surfaces in extreme deserts present the longest-lived landforms on Earth. Geological Society of America Bulletin 121: 688-697. 
McCalpin, J. 2009. Paleoseismology (Second Edition). Academic Press (Elsevier): 613 p. Burlington.

McQuarrie, N.; Horton, B.K.; Zandt, G.; Beck, S.; DeCelles, P.G. 2005. Lithospheric evolution of the Andean fold-thrust belt, Bolivia, and the origin of the central Andean plateau. Tectonophysics 399 (1-4): 15-37.

Melnick, D.; Bookhagen, B.; Strecker, M.R.; Echtler, H.P. 2009. Segmentation of megathrust rupture zones from forearc deformation patterns over hundreds to millions of years, Arauco peninsula, Chile. Journal of Geophysical Research 114: B01407.

Melnick, D.; Folguera, A.; Ramos, V. 2006. Structural control on arc volcanism: The Caviahue-Copahue complex, Central to Patagonian Andes transition ( $\left.38^{\circ} \mathrm{S}\right)$. Journal of South American Earth Sciences 22: 66-88.

Mercier, J. 1976. La néotectonique: Ses méthodes et ses buts. Revue Geographie Physique et Geologie Dynámique 18 (2): 323-346.

Metcalf, K.; Kapp, P. 2015, Along-strike variations in crustal seismicity and modern lithospheric structure of the central Andean forearc. In Geodynamics of a Cordilleran Orogenic System: The Central Andes of Argentina and Northern Chile (DeCelles, P.G.; Ducea, M.N.; Carrapa, B.; Kapp, P.A.; editors). Geological Society of America Memoir 212: 61-78.

Miyakawa, A.; Otsubo, M. 2015. Effect of a change in the state of stress on the likelihood of inland fault failure during the Mw 6.6 Iwaki earthquake resulting from the Mw 9.0 2011 Tohoku earthquake, Japan. Tectonophysics 661: 112-120.

Mora, C.; Comte, D.; Russo, R.; Gallego, A.; Mocanu, V. 2010. Aysen seismic swarm (January 2007) in southern Chile: analysis using joint hypocentral determination. Journal of Seismology 14 (4): 683-691.

Moreno, H.; Parada, M.A. 1976. Esquema geológico de la Cordillera de los Andes entre los paralelos $39^{\circ}$ y 41³0'S. In Congreso Geológico Chileno, No. 1: A213-A226. Santiago.

Mörner, N. 1994. Neotectonics in new perspectives. Bulletin INQUA Neotectonics Commission 18: 63-65.

Mpodozis, C.; Ramos, V.A. 1989. The Andes of Chile and Argentina. In Geology of the Andes and its Relation to Hydrocarbon and Mineral Resources (Ericksen, G.E.; Cañas, M.T.; Reinemud, J.A.; editors). Circumpacific Council for Energy and Mineral Resources. Earth Sciences Series 11: 59-90. Houston.

Mpodozis, C.; Ramos, V.A. 2008. Tectónica jurásica en Argentina y Chile: extensión, subducción oblicua, rifting, deriva y colisiones? Revista de la Asociación Geológica Argentina 63: 481-497.
Mpodozis, C.; Cornejo, P. 2012. Cenozoic Tectonics and Porphyry Copper Systems of the Chilean Andes. Society of Economic Geologists, Inc. Special Publication 16: 329-360.

Müller, R.D.; Roest, W.R.: Royer, J.Y.; Gahagan, L.M.; Sclater, J.G. 1997. Digital isochrons of the world's ocean floor. Journal of Geophysical Research 102 (B2): 3211-3214.

Muñoz, J.; Stern, C.R.R. 1988. The quaternary volcanic belt of the southern continental margin of South America: transverse structural and petrochemical variations across the segment between $38^{\circ} \mathrm{S}$ and $39^{\circ} \mathrm{S}$. Journal of South American Earth Sciences 1: 147-161.

Muñoz, N.; Charrier, R. 1996. Uplift of the western border of the Altiplano on a west-vergent thrust system, Northern Chile. Journal of South American Earth Sciences 9: 171-181.

Naranjo, J.A. 1987. Interpretación de la actividad cenozoica superior a lo largo de la Zona de Falla Atacama, Norte de Chile. Revista Geológica de Chile 31: 43-55. doi: 10.5027/andgeoV14n2-a06.

Nelson, A.R. 1992. Lithofacies analysis of colluvial sediments-An aid in interpreting the recent history of quaternary normal faults in the Basin and Range Province, Western United States. Journal of Sedimentary Petrology 62 (4): 607-621.

Nettles, M.; Ekström, G.; Koss, H.C. 2011. Centroidmoment-tensor analysis of the 2011 off the Pacific coast of Tohoku earthquake and its larger foreshocks and aftershocks. Earth Planets Space 63 (7): 519-523.

New, M.; Lister, D.; Hulme, M.; Makin, I. 2002. A highresolution data set of surface climate over global land areas. Climate Research 21: 1-25.

Okada, A. 1971. On the neotectonics of the Atacama Fault Zone region. Preliminary notes on late Cenozoic faulting and geomorphic development of Coast Range of northern Chile. Bulletin of the Department of Geography Kyoto University 3: 47-65.

Ostenaa, D.A. 1984. Relationships affecting estimates of surface fault displacements based on scarp-derived colluvial deposits. Geological Society of America, Abstracts with programs 16 (5): p. 327.

Pankhurst, R.; Hervé, F. 2007. Introduction and overview Earthquakes in Chile. In The Geology of Chile (Moreno, T.; Gibbons, W.; editors). Geological Society: 263287. London.

Pankhurst, R.; Hervé, F.; Rojas, L.; Cembrano, J. 1992. Magmatism and tectonics in continental Chiloe', Chile (42 ${ }^{\circ}$ and $42^{\circ} 30^{\prime} \mathrm{S}$ ). Tectonophysics 205: 283-294. 
Pardo, M.; Comte, D.; Monfret, T. 2002. Seismotectonic and stress distribution in the central Chile subduction zone. Journal of South American Earth Sciences 15: 11-22.

Paris, G.; Machette, M.N.; Dart, R.L.; Haller, K.M. 2000. Database and map of Quaternary faults and folds in Colombia and its offshore region, U.S. Geological Survey Open File Report 00-0284. PDF file of map of Quaternary faults and folds in Columbia prepared as part of the World Map of Major Active Faults with locations, ages, and activity rates of major earthquakerelated features accompanied by database of description and activity: http://pubs.usgs.gov/of/2000/ofr-00-0284/ (las visit 28-11-2018).

Pavlides, S. 1989. Looking for a definition of Neotectonics. Terra Nova 1: 233-235.

Pelayo, A.; Wiens, D. 1989. Seismotectonics and relative plate motions in the Scotia sea region. Journal of Geophysical Research 94: 7293-7320

Pérez, A.; Ruiz, J.A.; Vargas, G.; Rauld, R.; Rebolledo, S.; Campos J. 2014. Improving seismotectonics and seismic hazard assessment along the San Ramon Fault at the eastern border of Santiago city, Chile. Natural Hazards 71: 243-274.

Pérez-Flores, P.; Cembrano, J.; Sánchez-Alfaro, P.; Veloso, E.; Arancibia, G.; Roquer, T. 2016. Tectonics, magmatism and paleo-fluid distribution in a strike-slip setting: Insights from the northern termination of the Liquiñe Ofqui Fault System, Chile. Tectonophysics 680: 192-210.

PMA (Proyecto Multinacional Andino). 2009. Geociencia para las Comunidades Andinas. Atlas de deformaciones cuaternarias de los Andes. Servicio Nacional de Geología y Minería, Publicación Geológica Multinacional 7: 320 p., 1 mapa en CD. Santiago.

Radic, J.P. 2010. Las cuencas cenozoicas y su control en el volcanismo de los Complejos Nevados de Chillán y Copahue-Callaqui (Andes del Sur, 36-39 $\mathrm{S}$ ). Andean Geology 37 (1): 220-246. doi: 10.5027/ andgeoV37n1-a09.

Ramos, V.A. 2009a. The tectonic regime along the Andes: Present-day and Mesozoic regimes. Geological Journal 45 (1): 2-25.

Ramos, V.A. 2009b. Anatomy and global context of the Andes: Main geologic features and the Andean orogenic cycle. In Backbone of the Americas: Shallow Subduction, Plateau Uplift, and Ridge and Terrane Collision (Kay, S.M.; Ramos, V.A.; Dickinson, W.R.; editors). Geological Society of America Memoir 204: 31-65.
Rauld, R. 2002. Análisis morfoestructural del frente cordillerano de Santiago oriente, entre el río Mapocho y la quebrada de Macul. Memoria de Título (Inédito), Universidad de Chile: $57 \mathrm{p}$.

Rauld, R. 2011. Deformación cortical y peligro sísmico asociado a la Falla San Ramón en el frente cordillerano de Santiago, Chile central $\left(33^{\circ} \mathrm{S}\right)$. Tesis de Ph.D. (Inédito), Universidad de Chile, Departamento de Geología: 311 p.

Rehak, K.; Strecker, M.; Echtler, H. 2008. Morphotectonic segmentation of an active forearc, $37^{\circ}-41^{\circ} \mathrm{S}$, Chile. Geomorphology 94 (1-2): 98-116.

Reutter, K.-J.; Scheuber, E.; Helmcke, D. 1991. Structural evidence of orogen-parallel strike slip displacements in the Precordillera of northern Chile. Geologische Rundschau 80: 135-153.

Reutter, K.-J.; Scheuber, E.; Chong, G. 1996. The Precordilleran fault system of Chuquicamata, Northern Chile: evidence for reversals along arc parallel strikeslip faults. Tectonophysics 259: 213-228.

Riquelme, R.; Martinod, J.; Hérail, G.; Darrozes, J.; Charrier, R. 2003. A geomorphological approach to determining the Neogene to Recent tectonic deformation in the Coastal Cordillera of northern Chile (Atacama). Tectonophysics 361: 255-275.

Riquelme, R.; Hérail, G.; Martinod, J.; Charrier, R.; Darrozes, J. 2007. Late Cenozoic geomorphologic signal of Andean forearc deformation and tilting associated with the uplift and climate changes of the Southern Atacama Desert $\left(26^{\circ} \mathrm{S}-28^{\circ} \mathrm{S}\right)$. Geomorphology 86: 283-306.

Rosenau, M. 2004. Tectonic and geomorphic evolution of the southern Andean intra-arc zone between latitudes $38^{\circ}$ and $42^{\circ}$ S. Ph.D. Thesis (Unpublished), Freie Universität: $156 \mathrm{p}$.

Rosenau, M.; Melnick, D.; Echtler, H. 2006. Kinematic constraints on intra-arc shear and strain partitioning in the Southern Andes between $38^{\circ} \mathrm{S}$ and $42^{\circ} \mathrm{S}$ latitude. Tectonics 25: TC4013.

Ruiz, J.A.; Hayes, G.P.; Carrizo, D.; Kanamori, H.; Socquet, A.; Comte, D. 2014 Seismological analyses of the 2010 March 11, Pichilemu, Chile Mw 7.0 and Mw 6.9 coastal intraplate earthquakes. Geophysical Journal International 197: 414-434.

Ryder, I.; Rietbrock, A.; Kelson, K.; Bürgmann, R.; Floyd, M.; Socquet, A.; Vigny, C.; Carrizo, D. 2012. Large extensional aftershocks in the continental forearc triggered by the 2010 Maule earthquake, Chile. Geophysical Journal International 188: 879-890. 
Salazar, P. 2011. The upper crustal microseismicity image from the north Chilean subduction zone: implication for tectonics and fluid migration. Ph.D. Thesis (Unpublished), Freie Universität: 145 p.

Sánchez, P.; Pérez-Flores, P.; Arancibia, G.; Cembrano, J.; Reich, M. 2013. Crustal deformation effects on the chemical evolution of geothermal systems: the intra-arc Liquiñe-Ofqui Fault System, Southern Andes. International Geology Review: 37-41.

SARA (South America Risk Assessment Project). 2016. Research Topic 2 (RT2): Building a harmonised database of 'hazardous' crustal faults. https://sara.openquake. org/hazard_rt2 (last visit 28-11-2018).

Scheuber, E.; Andriessen, A. M. 1990. The kinematics and geodynamic significance of the Atacama Fault Zone, northern Chile. Journal of Structural Geology 12 (2): 243-257.

Scheuber, E.; González, G. 1999. Tectonics of the JurassicEarly Cretaceous magmatic arc of the north Chilean Coastal Cordillera (228-268S): a story of crustal deformation along a convergent plate boundary. Tectonics 18: 895- 910.

Scholz, C.H. 1988. The brittle-plastic transition and the depth of seismic faulting. Geologische Rundschau 77: 319-328.

Scholz, C.H.; Campos, J. 2012. The seismic coupling of subduction zones revisited. Journal of Geophysical Research 117: B05310.

Schwartz, D.P.; Coppersmith, K.J. 1986. Seismic hazard: new trends in analysis using geologic data. In Active Tectonics, Studies in Geophysics (Wallace, R.E.; editor). National Academy Press: 215-230. Washington, D.C.

Seeber, L.; Armbruster, J.G. 2000. Earthquakes as beacons of stress change. Nature 407: 69-72.

Sepúlveda, S.; Astroza, M.; Kausel, E.; Campos, J.; Casas, E.; Rebolledo, S.; Verdugo, R. 2008. Newfindings on the 1958 Las Melosas earthquake sequence, Central Chile: implications for seismic hazard related to shallow crustal earthquake in subduction zones. Journal of Earthquake Engineering 12: 432-455.

SERNAGEOMIN. 2003. Mapa Geológico de Chile: versión digital. Servicio Nacional de Geología y Minería, Publicación Geológica Digital, No. 4 (CD-ROM, versión1.0, 2003). Santiago.

Sibson, R.H. 1984. Roughness at the base of the seismogenic zone: contributing factors. Journal of Geophysical Research 89: 5791-5799.

Sibson, R.H. 1992. Implications of fault-valve behaviour for rupture nucleation and recurrence. Tectonophysics 211: 283-293.
Sibson, R.H. 1994. Crustal stress, faulting, and fluid flow. In Geofluids: Origin, Migration and Evolution of Fluids in Sedimentary Basins (Parnell, J.; editor), Geological Society London Special Publications 78: 69-84.

Sibson, R.H. 2002. Geology of the Crustal Earthquake Source. In International Handbook of Earthquake and Engineering Seismology (Lee, W.H.K.; Kanamori, H.; Jennings, P.; Kisslinger, C.; editors). Academic Press 81A (29): 455-473. London.

Sielfeld, G.; Lange, D.; Cembrano, J. 2017. Intra-arc Seismicity: Geometry and Kinematic Constraints of Active Faulting along Northern Liquiñe-Ofqui and Andean Transverse Fault Systems $\left(38^{\circ}\right.$ and $40^{\circ} \mathrm{S}$, Southern Andes). American Geophysical Union, Abstract: T23D-0632. New Orleans.

Silva, N. 2008. Caracterización y Determinación del Peligro Sísmico en la Región Metropolitana. Memoria de Título (Inédito), Universidad de Chile, Departamento de Ingeniería Civil: 148 p.

Slemmons, D.B. 1977. State of the art for assessing earthquake hazard inthe United States, Report 6; faults and earthquake magnitude: U.S. Army Corps of Engineers, Waterways Experiment Station,Vicksburg, Mississippi, Miscellaneous Paper S-73-1: 129 p.

Slemmons, D.B. 1995. Complications in making paleoseismic evaluations in the Basin and Range province, western United States. In Perspectives in Paleoseismology (Serva, L.; Slemmons, D.B.; editors). Bulletin of the Association of Engineering Geologists, Special Publications 6: 19-34.

Slemmons, D.B.; DePolo, C. M. 1986. Evaluation of active faulting and related hazards. In Active Tectonics, Studies in Geophysics (Wallace, R.E.; editor). National Academic Press: 45-62. Washington, DC.

Smalley, R.Jr.; Kendrick, E.; Bevis, M.; Dalziel, I.; Taylor, F.; Lauria, E.; Barriga, R.; Casassa, G.; Olivero, E.; Piana, E. 2003. Geodetic determination of relative plate motion and crustal deformation across the Scotia-South America plate boundary in eastern Tierra del Fuego. Geochemistry, Geophysics, Geosystems 4 (9): 1-19.

Smith, R.B.; Bruhn, R.L. 1984. Intraplate extensional tectonics of the eastern Basin-Range: inferences on structural style from seismic reflection data, regional tectonics, and thermo- mechanical models of brittleductile deformation. Journal of Geophysical Research 89: 5733-5762.

Sobolev, S.V.; Babeyko, A.Y. 2005. What drives orogeny in the Andes? Geology 33 (8): 617-620.

Stanton-Yonge, A.; Griffith, W.A.; Cembrano, J.; St. Julien, R.; Iturrieta, P. 2016. Tectonic role of margin- 
parallel and margin-transverse faults during oblique subduction in the Southern Volcanic Zone of the Andes: Insights from Boundary Element Modeling. Tectonics 35: 1990-2013.

Stein, C.A. 2003. Heat flow and flexure at subduction zones. Geophysical Research Letters 8155 (30). doi: 10.1029/2003GL018478.

Stein, R.S. 1999. The role of stress transfer in earthquake occurrence. Nature 402 (6762): 605-609.

Stein, R.S.; King, G.C.P.; Lin, J. 1994. Stress triggering of the $1994 \mathrm{M}=6.7$ Northridge, California, earthquake by its predecessors. Science 265 (5177): 1432-1435.

Stewart, I.S.; Hancock, P.L. 1994. Neotectonics. In Continental deformation (Hancock, P.L.; editor). Pergamon Press: 370-409. New York.

Stirling, M.; Goded, T.; Berryman, K.; Litchfield, N. 2013. Selection of Earthquake Scaling Relationships for Seismic-Hazard Analysis. Bulletin of the Seismological Society of America 103 (6): 2993-3011.

Suárez, G.; Comte, D. 1993. Comment on "Seismic coupling along the Chilean Subduction Zone" by B. W. Tichelaar and L. R. Ruff. Journal of Geophysical Research, Solid Earth 98 (B9): 15825-15828.

Tardani, D.; Reich, M.; Roulleau, E.; Takahata, N.; Sano, Y.; Peréz-Flores, P.; Sánchez, P.; Cembrano, J.; Arancibia, G. 2016. Exploring the structural controls on helium, nitrogen and carbon isotope signatures in hydrothermal fluids along an intra-arc fault system. Geochimica et Cosmochimica Acta 184:193-211

Tassara, A.; Yáñez, G. 1996. Thermomechanic segmentation of the Andes (158-508S): a flexural analysis approach. In International Symposium on Andean Geodynamics, No. 3, ISAG: 115-118. St. Malo.

Tassara, A.; Yáñez, G. 2003. Relación entre el espesor elástico de la litosfera y la segmentación tectónica del margen andino $\left(15-47^{\circ} \mathrm{S}\right)$. Revista Geológica de Chile 30 (2): 159-186. doi: 10.5027/andgeoV30n2-a02.

Tassara, A.; Swain, C.; Hackney, R.; Kirby, J. 2007. Elastic thickness structure of South America estimated using wavelets and satellite-derived gravity data. Earth and Planetary Science Letters 253: 17-36.

Thomas, T.; Livermore, R.A.; Pollitz, F. 2003. Motion of the Scotia Sea plates. Geophysical Journal International 155: 789-804.

Thomson, S.N. 2002. Late Cenozoic geomorphic and tectonic evolution of the Patagonian Andes between latitudes $42^{\circ}$ and $46^{\circ} \mathrm{S}$ : An appraisal based on fission-track results from the transpressional intra-arc Liquine-Ofqui fault zone. Geological Society of America, Bulletin 114 (9): 1159-1173.
Tibaldi, A.; Lagmay, A.M.F.A.; Ponomareva, V.V. 2005. Effects of basement structural and stratigraphic heritages on volcano behaviour and implications for human activities (The UNESCO/IUGS/IGCP project 455). Episodes 28: 158-170.

Tichelaar, B.W., Ruff, L.J. 1993. Depth of seismic coupling along subduction zones. Journal of Geophysical Research 98 (B2): 2017-2037.

Toda, S.R.; Lin, J.; Stein, S. 2011a. Using the $2011 \mathrm{Mw}$ 9.0 off the Pacific coast of Tohoku earthquake to test the Coulomb stress triggering hypothesis and to calculate faults brought closer to failure. Earth, Planets and Space 63 (7): 725-730.

Toda, S.R.; Stein, S.; Lin, J. 2011b. Widespread seismicity excitation throughout central Japan following the $2011 \mathrm{M}=9.0$ Tohoku earthquake and its interpretation by Coulomb stress transfer. Geophysical Research Letters 38: L00G03.

Tomlinson, A.; Blanco, N. 1997a. Structural evolution and displacement history of the west fault system, Precordillera, Chile: Part 1, synmineral history. In Congreso Geológico Chileno, No. 8, 3: 1883-1887. Antofagasta.

Tomlinson, A.; Blanco, N. 1997b. Structural evolution and displacement history of the west fault system, Precordillera, Chile: Part 2, postmineral history. In Congreso Geológico Chileno, No. 8, 3: 1878-1882. Antofagasta.

USGS. 2018a. ANSS (Advanced National Seismic System) Comprehensive Earthquake Catalog (ComCat) Documentation. https://earthquake.usgs.gov/earthquakes/ search (last visit 28-11-2018).

USGS. 2018b. Earthquake Glossary. Earthquake Hazards Program. http://earthquake.usgs.gov/learn/ glossary/?term=active\%20fault (last visit 28-11-2018).

Uyeda, S.; Kanamori, H. 1979. Back-arc opening and the mode of subduction. Journal Geophysical Research 84: 1049-1061.

Vargas, G.; Palacios, C.; Reich, M.; Luo, S.; Shen, C.; González, G. 2011. U-series dating of co-seismic gypsum and submarine paleoseismology of active faults in Northern Chile $\left(23^{\circ} \mathrm{S}\right)$. Tectonophysics 497: 34-44.

Vargas, G.; Rebolledo, S.; Sepúlveda, S.A.; Lahsen, A.; Thiele, R.; Townley, B.; Padilla; C.; Rauld, R. Herrera, M.J.; Lara, M. 2013. Submarine earthquake rupture, active faulting and volcanism along the major Liquiñe-Ofqui Fault Zone and implications for seismic hazard assessment in the Patagonian Andes. Andean Geology 40 (1): 141-171. doi: 10.5027/andgeo V40n1-a07. 
Vargas, G.; Klinger Y.; Rockwell T.; Forman S.L.; Rebolledo S.; Baize S.; Lacassin R.; Armijo R. 2014. Probing large intra-plate earthquakes at the west flank of the Andes. Geology 42: 1083-1086.

Villalobos-Claramunt, A.; Vargas, G.; Maksymowicz, A.; Lastras, G. 2015. Evidencias paleosismológicas del origen cortical de la Crisis Sísmica del año 2007 en la región de Aysén. In Congreso Geológico Chileno, No. 14: 306-309. La Serena.

Vita-Finzi, C. 1987. Recent Earth Movements. Academic Press: 226 p. London.

Wallace, R.E. 1981. Active faults, paleoseismology and earthquake hazards in the Western United States. In Earthquake Prediction (Simpson, D.; Richards, P.; editors). American Geophysical Union, M. Ewing Series 4: 209-216.

Wallace, R.E. 1986. Active Tectonics: Studies in Geophysics. National Academy Press: 280 p. Washington, D.C.

Wang, K.; Hu, Y.; Bevis, M.; Kendrick, E.; Smalley Jr.; R.; Vargas, R.B.; Lauria, E. 2007. Crustal motion in the zone of the 1960 Chile earthquake: Detangling earthquake-cycle deformation and forearc-sliver translation. Geochemistry, Geophysics, Geosystems 8 (10): 1-14.

Wells, C.; Coppersmith, K. 1994. New empirical relationships among Magnitude, Rupture Length, Rupture Width, Rupture Area and Surface Displacement.
Bulletin of the Seismological Society of America 84: 974-1002.

Wesnousky, S.G. 2008. Displacement and geometrical characteristics of earthquake surface ruptures: Issues and implications for seismic hazard analysis and the process of earthquake rupture. Bulletin of the Seismological Society of America 98 (4): $1609-1632$.

Yáñez, G.; Cembrano, J. 2004. Role of viscous plate coupling in the late Tertiary Andean tectonics. Journal of Geophysical Research 109 (B02407): 1-21.

Yáñez, G.; Gana, P.; Fernández, R. 1998. Origen y significado geológico de la Anomalía Melipilla, Chile central. Revista Geológica de Chile 25: 175-198. doi: 10.5027/andgeoV25n2-a05.

Yáñez, G.; Ranero, C.; Von Huene, R.; Diaz, J. 2001. Magnetic anomaly interpretation across the southern Central Andes (328-33.58S): the role of the Juan Fernandez ridge in the late Tertiary evolution of the margin. Journal of Geophysical Research 106: 6325-6345.

Yeats, R.; Sieh, K.; Allen, C. 1997. The Geology of Earthquakes. Oxford University Press: 568 p. Oxford.

Yepes, H.; Audin, L.; Alvarado, A.; Beauval, C.; Aguilar, J.; Font, Y.; Cotton, F. 2016. A new view for the geodynamics of Ecuador: Implication in seismogenic source definition and seismic hazard assessment. Tectonics 35 (5): 1249-1279.

Manuscript received: May 16, 2017; revised/accepted: August 13, 2018; available online: September 28, 2018. 